\title{
FROM PAGAN TO CHRISTIAN: RELIGIOUS ICONOGRAPHY IN MATERIAL GULTURE FROM SAGALASSOS
}

\author{
Peter Talloen
}

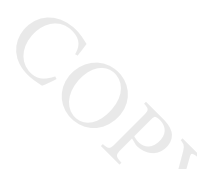

\section{Abstract}

The evidence of domestic artefacts bearing religiously inspired imagery from Sagalassos (south-west Turkey) is used here to trace how the religious revolution of Late Antiquity affected daily life and how that evidence may reflect wider patterns in the shift from a pagan to a Christian culture in Late Antiquity. After a period characterised by a common iconographic repertoire shared by pagans and Christians alike, in which the Christian impact on material culture was limited, the material expression of the changing religious atmosphere became more visible from the second half of the 4th c. onwards and eventually resulted in a canonic Christian iconography.

\section{INTRODUCTION}

The material culture of Late Antiquity is relatively underexplored, particularly its potential to reflect religious belief and practice. ${ }^{1}$ It is of course far from easy to identify religious behaviour on the basis of artefacts alone, and we must always keep in mind that the categories of 'Christian' and 'pagan' are neither as homogeneous nor as mutually exclusive as is often assumed. Nevertheless, the period from the early 4th c. to the early 7 th c. witnessed a gradual yet dramatic transformation in the religious identity of the Mediterranean world. It is the aim of this article to shed some light on that transformation by examining the evidence of domestic artefacts bearing religiously inspired imagery from Sagalassos, and how that evidence may reflect wider patterns in the shift from a pagan to a Christian culture in Late Antiquity.

${ }^{1}$ For an introduction see Russell (1982); also see Dark (2004) 1-3 on the archaeology of Byzantine everyday life. 
Sagalassos has been the focus of extensive archaeological research in recent years. ${ }^{2}$ A prominent Late Roman provincial city and pottery production centre in the ancient region of Pisidia (south-western Turkey), Sagalassos was an active urban settlement in the 4th to 6th c. before being abandoned in the 7th c. and has preserved a variety of artefacts from across the late antique period. These finds include a considerable number of domestic utensils which offer a somewhat neglected but highly important window into social and religious life. ${ }^{3}$ The iconography present on such items cannot simply be dismissed as decoration, but rather, as the evidence from Sagalassos demonstrates, offers us an opportunity to trace how the religious revolution of Late Antiquity affected daily life at a level accessible to all. ${ }^{4}$

\section{Christ and Dionysus: The 4th C. Bagkground and the Rise of Christian Material Culture}

Prior to the 4th c., the Christian impact on material culture was limited to say the least. ${ }^{5}$ The majority of extant pre-Constantinian Christian art is funerary in nature, and only gradually were familiar Graeco-Roman artefacts and symbols adapted for Christian use. Following the 'conversion' of Constantine in A.D. 312 imperial support enabled Christians to redefine their identity in a new context of religious respectability. Yet, while numerous Christian communities are attested in the 4th c., throughout the eastern Mediterranean, they left little imprint on the material culture of daily life at that stage. Everyday or domestic items bearing recognizable Christian symbols only

${ }^{2}$ On Sagalassos in the late antique period, see recently Waelkens et al. (2006).

${ }^{3}$ It is of course understood that the majority of items used in daily life have long been lost, as they were made out of organic materials such as wood, leather or cloth. Ceramics and items of stone, glass or metal do survive, although the last two categories were easily melted down for reuse and what we possess thus represents only a fraction of what was originally in existence.

${ }^{4}$ The limited percentage of pottery with religiously inspired decoration compared to the total output of ceramic production, for instance, identifies these items as intentional statements. Moreover, the close correspondence between decorated pottery and artefacts of cultic activity allows us to use it as a guide to religious actuality: Talloen and Poblome (2005). For a similar study on the Levant see Ribak (2004), who demonstrates that everyday artefacts bearing religiously inspired symbols were actively used to assert religious identity in daily life and can therefore help to determine the religious persuasion of their users.

5 Jensen (2000), Snyder (2003). 
appeared from the second half of the 4th c. onwards, and in most areas of the empire, including Pisidia, we must wait until the 5th c. ${ }^{6}$

This lack of physical evidence is not due to a failure of the archaeological record. Rather, it corresponds to the close relationship between Christians and non-Christians. The early Christians utilised traditional household settings and items and generally their material remains cannot be distinguished from the contemporary non-Christian culture. Thus there was a common iconographic repertoire shared by pagans and Christians alike, including idyllic-bucolic scenes of harvest and the 'good shepherd', and subjects such as the praying figure or orans. ${ }^{7}$ For many of these scenes their meaning would have depended on their physical context and the interpretation of the viewer. The formal and narrative fluidity of such interchangeable imagery echoes a flexibility of meaning and interpretation found widely in Late Antiquity. ${ }^{8}$ It also illustrates the fact the boundaries between pagan and Christian communities in the 4th c. were not as rigid as some contemporary historians would have us believe. ${ }^{9}$

The material expression of the changing religious atmosphere begins to become more visible from the second half of the 4th c. onwards. Some of the earliest indications for the development of an explicitly Christian material culture are provided by African Red Slip Ware. This pottery was widely exported and was the principal tableware throughout the eastern Mediterranean in the 3rd and 4th c. ${ }^{10}$ The Christian subject matter of these North African ceramics consists primarily of scenes of deliverance, with a predominance of Old Testament figures believed to refer to the life of Christ and the salvation offered by the Church, notably Daniel and Jonah. ${ }^{11}$ The popular cult of the martyrs, who through their suffering reproduced the passion of Christ himself, also featured among the first Christian topics to be represented on

\footnotetext{
${ }^{6}$ Talloen and Poblome (2005) 70-73. The same pattern is visible in Athens: Castrén (1999) 213; and Corinth: Sanders (2005) 420.

7 These were well-known late antique motifs with an allegorical connotation. See Snyder (2003) 23-66 for an overview of these and other Early Christian symbols.

${ }^{8}$ Elsner (1998) 153.

${ }^{9}$ Bayliss (2004) 30 and n. 256.

${ }^{10}$ For a comprehensive overview of the imagery present on African ceramics, see recently Herrmann and van den Hoek (2002).

${ }^{11}$ Garbsch and Overbeck (1989) 127-33; Herrmann and van den Hoek (2002) 28-45.
} 
decorated African pottery. ${ }^{12}$ Yet the depiction of these biblical subjects drew in turn on long-standing pagan artistic traditions, including the depiction of Daniel and Jonah in the nude, like pagan heroes.

African Red Slip Ware is, in any case, an exception to the rule. Most other centres of artefact production did not yet produce explicitly Christian items in the 4th c. By and large, contemporary material culture still reflected ongoing pagan traditions, with a host of heroes and deities continuing to feature on domestic objects. The most prominent pagan figures include Apollo, Heracles and Achilles, but one deity in particular appears to have been the focus of much attention in Sagalassos and throughout the eastern Mediterranean during the 4th c. A.D., namely Dionysus. ${ }^{13}$ His popularity is attested both in literary sources (most notably the Dionysiaca of Nonnus of Panopolis) and material culture, and perhaps reflects his rising position in the pagan pantheon at that time. Indeed, Dionysus may have been promoted as an alternative to Christ, facilitated by their shared characteristics of miraculous birth, mystery cult and divine resurrection. ${ }^{14}$ Dionysus' image occurs on many different media, from mosaics and textiles to silver and bronze plate, and at a domestic level he is a prominent figure

\footnotetext{
${ }^{12}$ Garbsch and Overbeck (1989) 159-60; Herrmann and van den Hoek (2002) $56-60$.

${ }^{13}$ A deity present on the decorated pottery of Sagalassos since imperial times (Talloen and Poblome (2005) 63), Apollo remained popular in Late Antiquity, something that can be related to his embodiment of the divinity of the sun (Helios, Sol Invictus) with whom several emperors had identified themselves (MacMullen (1984) 44; MacCoull (1991) 136) and who also featured on African ceramics (Herrmann and van den Hoek (2002) 80-82). Heracles was also connected with the figure of the emperor as one of the protective divinities of the tetrarchy (Uhlenbrook (1986) 111), while according to some scholars his late antique prominence was in response to a need for a more personal religious experience through the suffering and apotheosis of the god (Uhlenbrook (1986) 14; Karivieri (2001) 185). His twelve labours feature commonly on different categories of material culture in Late Antiquity (African ceramics: Garbsch and Overbeck (1989) 175-78; Athenian lamps: Karivieri (2001) 185-92). According to Zosimus (4.18.2-4), Achilles still enjoyed worship in the late 4th c. An entire series of African Red Slip is devoted to his life, undoubtedly copies from similar decorations on metalwork (Garbsch and Overbeck (1989) 164-74), while his departure for the Trojan War was the topic for the central emblema of a late 4th c. mosaic at the Library of Sagalassos: Waelkens et al. (2000). Dionysus: Daszewski (1985); Parrish (1995). According to some scholars Dionysus was the great deity of the later Greek East: Bowersock (1990) 41-53, Huskinson (2004) 140.

${ }^{14}$ Daszewski (1985) 38-45; Bowersock (1990) 41-53. The birth of Dionysus is represented on the 4th c. floor mosaic from Nea Paphos and offers 'a striking pagan version of the theme of the epiphany of a divine child which would become one of Christianity's most significant iconographic forms' (Elsner (1998) 220).
} 
on tablewares, lamps and other decorated ceramics. Such Dionysiac imagery is a common feature of the pottery produced at Sagalassos, especially the oinophoroi, mould-made flasks that were probably used as portable wine containers, a type fit for the god of wine (fig. 1). Sagalassos wares decorated with Dionysiaca were exported to cities in neighbouring regions such as Perge in Pamphylia and Lycian Myra, and even as far as Carthage and Egypt. ${ }^{15}$

It has often been argued that by Late Antiquity mythological subjects such as the Dionysiaca had largely lost their pagan meaning. Popular deities had become mere personifications of natural forces or human qualities. Aphrodite personified beauty, while Dionysus represented earthly fertility. In this way Dionysus was no more than a neutralised mythological subject that made an appropriate adornment for a drinking party. ${ }^{16}$ To a degree, the evidence from Sagalassos might support this view. Yet equally, it can be argued that the Dionysiac imagery of the ceramics drew upon and reinforced correct rituals and propriety in honour of the god, and that this continued in the 4th c. in direct, if not always explicit, competition with the rise of Christianity.

In the imperial period, vessels with Dionysiac imagery were already extremely popular among the pottery produced in the city. ${ }^{17}$ As a type of tableware, Sagalassos Red Slip Ware was intended for use on the dining table, a focal point for sociability, where Dionysus - as the deity of the symposium - was at home. Decorative scenes generally included dancing, feasting and vine harvesting in narrative sequences, but Dionysus himself and other members of his ecstatic party, or thiasos like Pan and the satyrs, were equally present to partake in the pleasure of the dining room (fig. 2). In addition, Dionysus is represented on Sagalassos pottery in a state of drunkenness supported by a satyr, just as he appears in the statue groups displayed in the Antonine Nymphaeum on the city's Upper Agora, which was dedicated to the god (fig. 3). This evocation of statues of Dionysus suggests that the scenes on the pottery were based, at least in part, on local religious cult and practice. ${ }^{18}$

\footnotetext{
${ }_{15}$ Poblome (1998) 207-10.

${ }^{16}$ Buckton (1994) 39. Also Harl argues that many mythological motifs in the decorative arts of the 4th and 5th c. are best regarded as good taste rather than expressions of religious belief: Harl (1990) 16.

17 Talloen and Poblome (2005) 62-63.

18 Talloen and Poblome (2005) 63.
} 


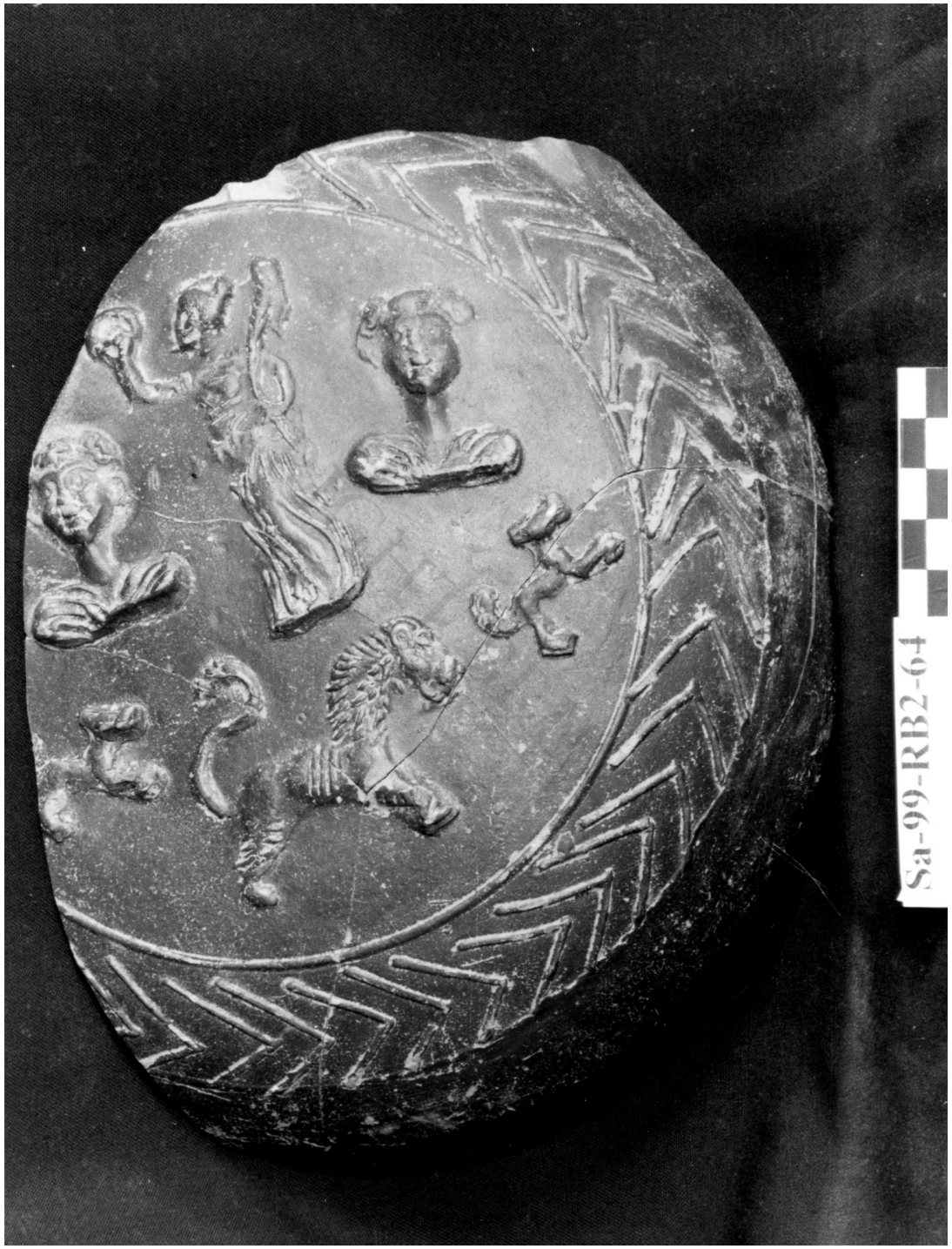

Fig. 1a

Fig. 1a-b Oinophoroi with Dionysiaca from Sagalassos: a) Oinophoros representing two busts of Dionysus, one of which is crowned by a standing winged Nike holding a palm branch, found at the Roman Baths of Sagalassos (inv. no. SA99RB2/64) and dated to the late 4th to early 5th c. (Sagalassos archive). 


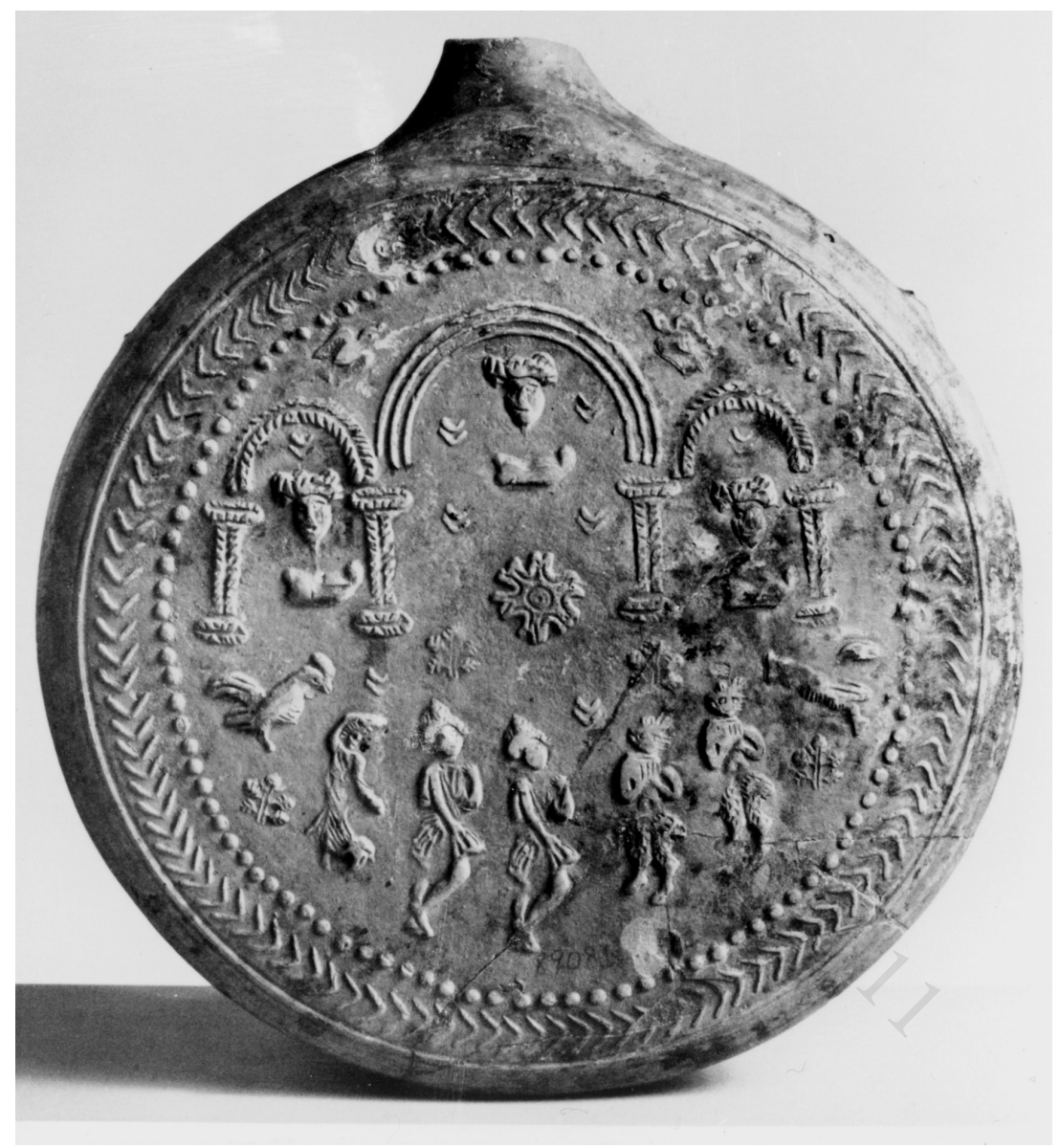

Fig. 1b

Fig. la-b Oinophoroi with Dionysiaca from Sagalassos: b) Oinophoros representing three busts of Dionysus underneath arcades preceded by members of the thiasos, found at an unknown location in Egypt where it is kept at the Museum for Egyptian Antiquities at Cairo (inv. no. J.E. 89081) and dated to the 5th c. (Courtesy of the Museum of Antiquities). 


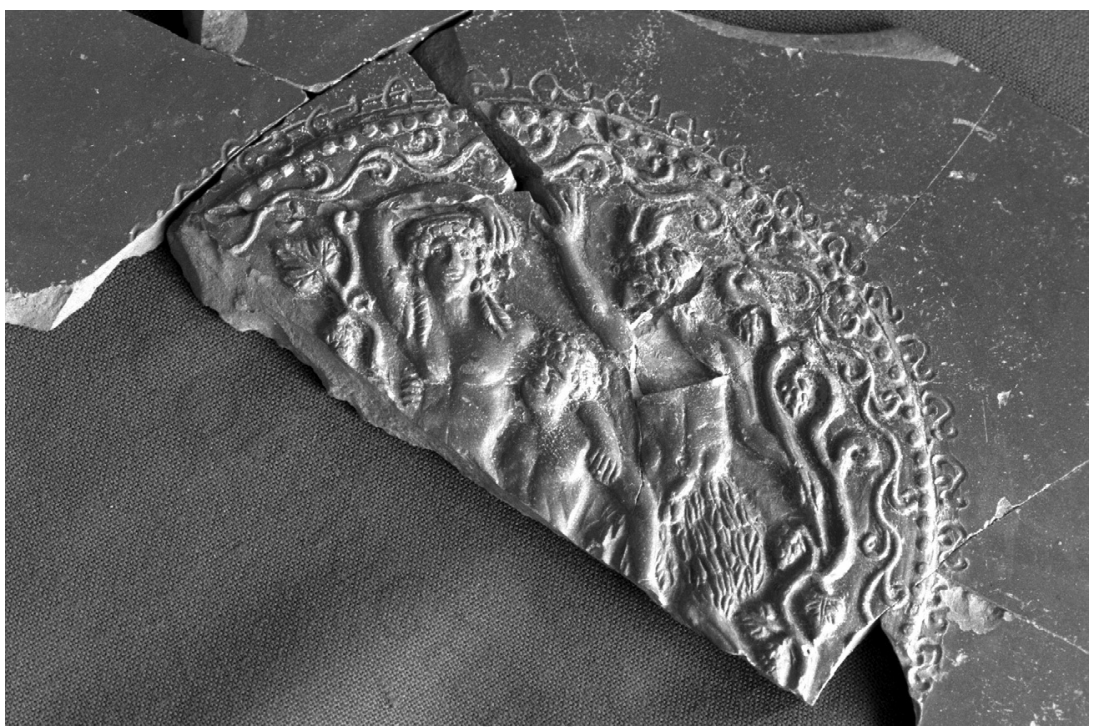

Fig. 2 Serving tray with a central medallion representing a drunken Dionysus supported by a satyr and accompanied by Pan, found at the Domestic Area (SA2001DA/93) and dated to the 2nd c. A.D. (Sagalassos archive)

Dionysiac iconography featured regularly in the Early and Middle Imperial period, but in the course of the 4 th $\mathrm{c}$. it achieved a virtual monopoly among the religiously inspired decorated pottery of Sagalassos. That such Dionysiac scenes were not merely invoking the god as a symbol of 'a good time' appears to be further corroborated by the treatment of the statues of Dionysus in the Upper Agora Nymphaeum that was dedicated to the god. Mythological sculpture generally persisted in the late antique urban landscape as part of the ancient heritage. ${ }^{19}$ In this instance, however, both corner aediculae housing effigies of Dionysus were sealed off by the local Christian community, as indicated by the crosses that were inscribed on the used building blocks, sometime during the 6th to early 7 th c. (fig. 4). ${ }^{20}$ This suggests that the god was perceived as a dangerous opponent by the Christians, who did not allow him to meet the public gaze, while other statuary of

19 Saradi-Mendelovici (1990); Hannestad (1994, 2002).

20 Waelkens et al. (1997) 151 and 162. Beside this nymphaeum, a temple was also dedicated to the deity (see Talloen and Vercauteren in this volume). Finally, the importance of his cult at Sagalassos is underlined by the fact that one of his priests was a Roman senator: Lanckoronski (1892) 229 no. 212. 


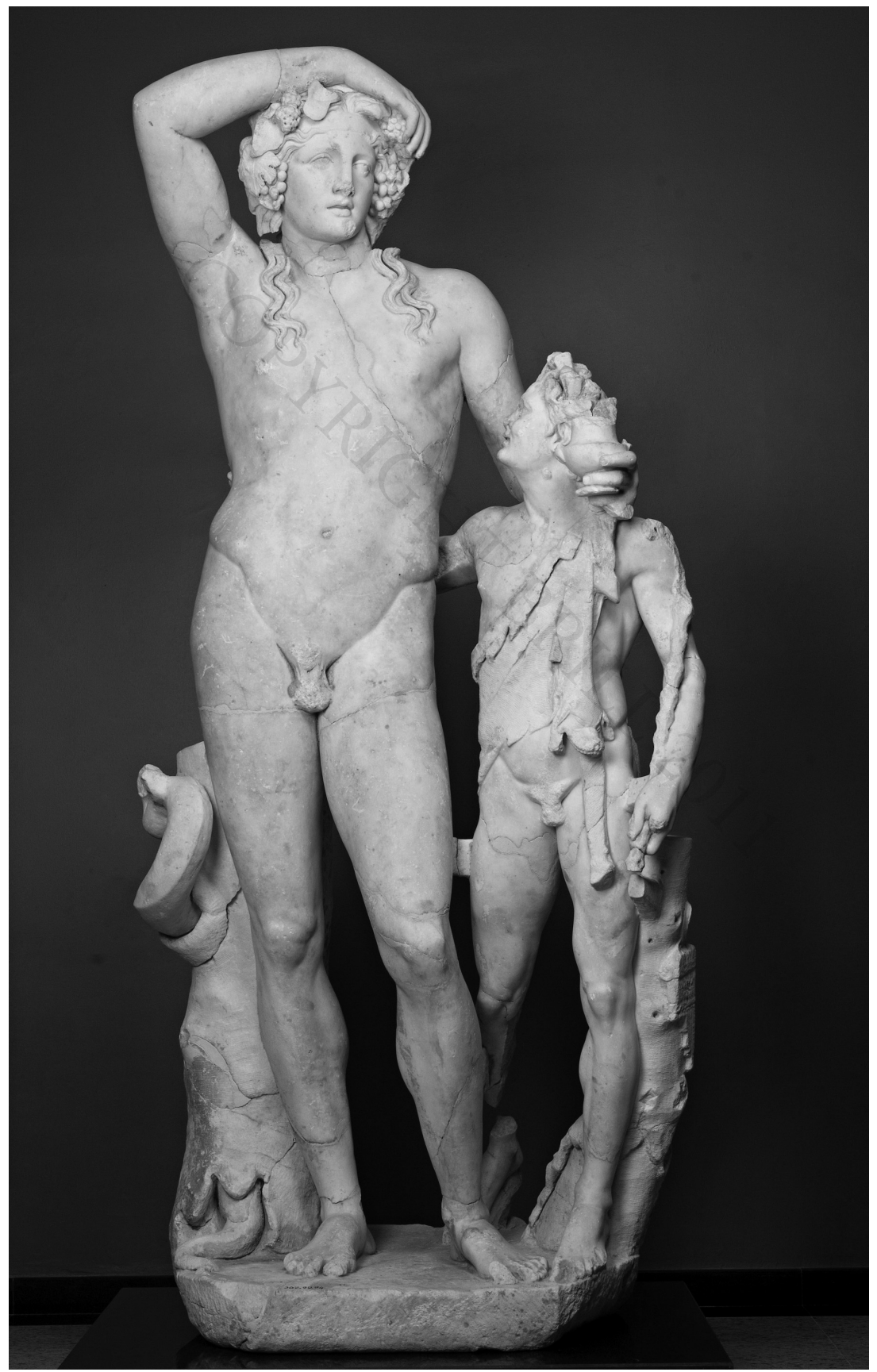

Fig. 3 Statue of a drunken Dionysus supported by a satyr, from the left aedicula of the nymphaeum on the Upper Agora and dated to the 2nd c. A.D. (Sagalassos archive) 


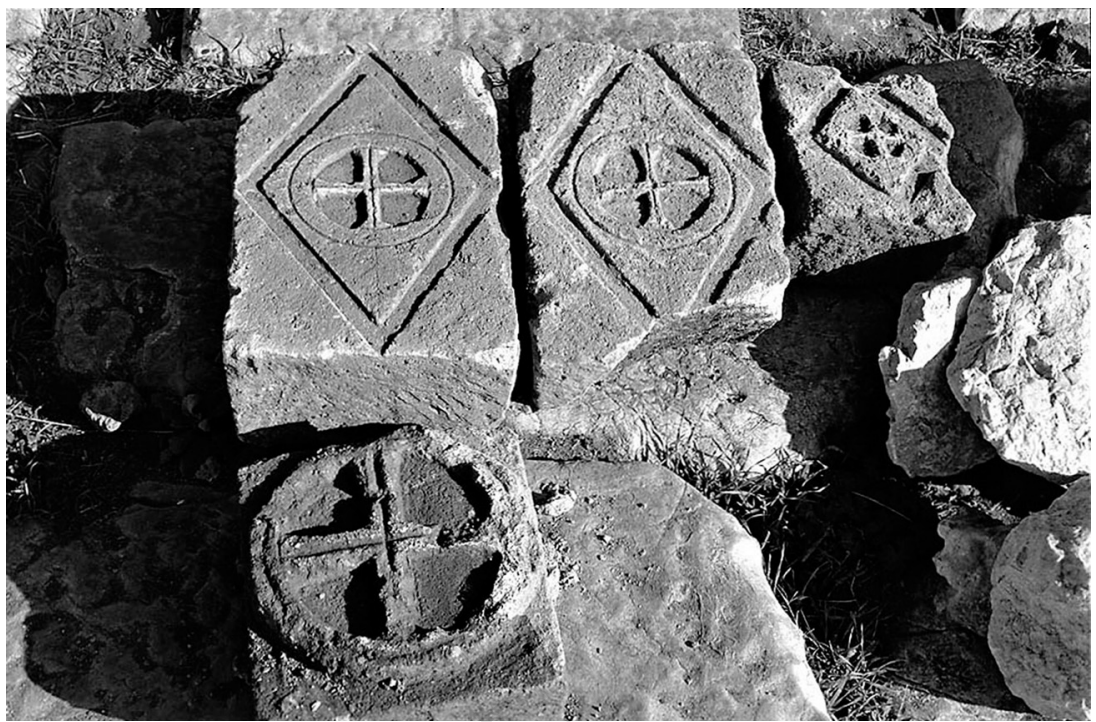

Fig. 4 Tufa blocks with inscribed crosses used to seal off the corner aediculae of the nymphaeum on the Upper Agora, dated to the 6th c. (Sagalassos archive).

Nike, Nemesis and Asclepius remained on the public stage. Moreover, the fact that the production of oinophoroi with Dionysiac imagery only began at Sagalassos in the 4th c., and continued into the 6th c., may indicate that Dionysus' cult was still vital and active at a time when the cities of the region were being openly Christianised. Although Dionysiac imagery does not always necessarily have a religious significance, this evidence suggests there was a degree of competition between Christianity and the popular local cult of Dionysus, and that Dionysiac and other mythological themes on pottery are open to a more spiritual or cultic interpretation than has often been assumed.

\section{Pagan and Christian Material Culture in 5Th and 6Th Gentury Sagalassos}

The Dionysiac imagery of the Sagalassos oinophoroi attests to the flourishing production of pagan imagery in the city well into the 6 th $\mathrm{c}^{21}$

${ }^{21}$ Dionysus also remained present in the urban context of Christian Sardis: Hanfmann and Buchwald (1983) 192. 
This accords with the evidence from elsewhere in the Mediterranean world. 'Images of myth evoked the rich imaginative world of religion, romance and education in the classical tradition which formed some of the key categories and principles by which the empire's citizens chose to live their lives'. ${ }^{22}$ Dionysus still appears on mosaics dated to the early 6th c., and was the pagan god who endured longest in the iconographical repertoire of African Red Slip Ware..$^{23}$ In Sagalassos, statues of Nike likewise remained visible in the public landscape of the city, and her image was also preserved on the locally produced oinophoroi. Whether such imagery indicates continuing cultic devotion is impossible to determine without more explicit evidence, as many pagan deities had become domesticated in Christian households. ${ }^{24}$ Yet, it is clear that in public monuments, and above all in private circles, paganism survived far longer and more extensively than our Christian sources would like us to believe. ${ }^{25}$

Nevertheless, it cannot be disputed that there was a significant shift in the material culture of the 5th and 6th $\mathrm{c}$. that came with the largescale Christianisation of Roman society from the end of the 4th c. onwards. The emergence of a Christian landscape on an imperial scale is reflected in turn in the iconography of everyday life. A whole range of ceramic household utensils, including plates, oinophoroi and oil lamps, gradually come to display specifically Christian symbols including crosses, cross-monograms and fishes (fig. 5). These motifs appear on Sagalassos Red Slip Ware, as well as African Red Slip Ware, Phocaean Red Slip Ware or Late Roman C ware, and Athenian lamps. ${ }^{26}$ The same Christian symbols also furnished metal appliances (locks,

${ }^{22}$ Elsner (1998) 99.

23 Mosaics: see for example the House of the Falconer at Argos: Akerström-Hougen (1974). African Red Slip Ware: Hayes (1972) 261-63 and fig. 50.223-24; Lund (2001) 205. The 62nd canon of the council of Trullo (A.D. 691-92) condemns the invocation of Dionysus during the vintage cycle, indicating that the god still enjoyed some veneration, even at the end of the 7 th c.: Trombley (1978).

${ }^{24}$ Rather than evidence of outright paganism on the part of their owners, these pagan motifs should be read as embodying ideas of plenty and good fortune, according to Maguire (1999) 246. The presence of pagan deities in their houses did not seem to bother the Christian owners. That said, it is possible that this relaxed attitude toward pagan art was a privilege of the well-to-do: Caseau (1999) 35.

${ }_{25}$ Trombley (1985) and (1993-94, 1); Harl (1990). The actions of the bishop of Ephesus in the 6th c., for instance, clearly demonstrate the tenacity of paganism: Whitby (1991).

${ }_{26}$ See respectively Talloen and Poblome (2005) 70-73, Lund (2001) 202, Vaag (2001) 219-22, Ladstätter and Sauer (2005) 152 and Karavieri (2001) 192-93. 


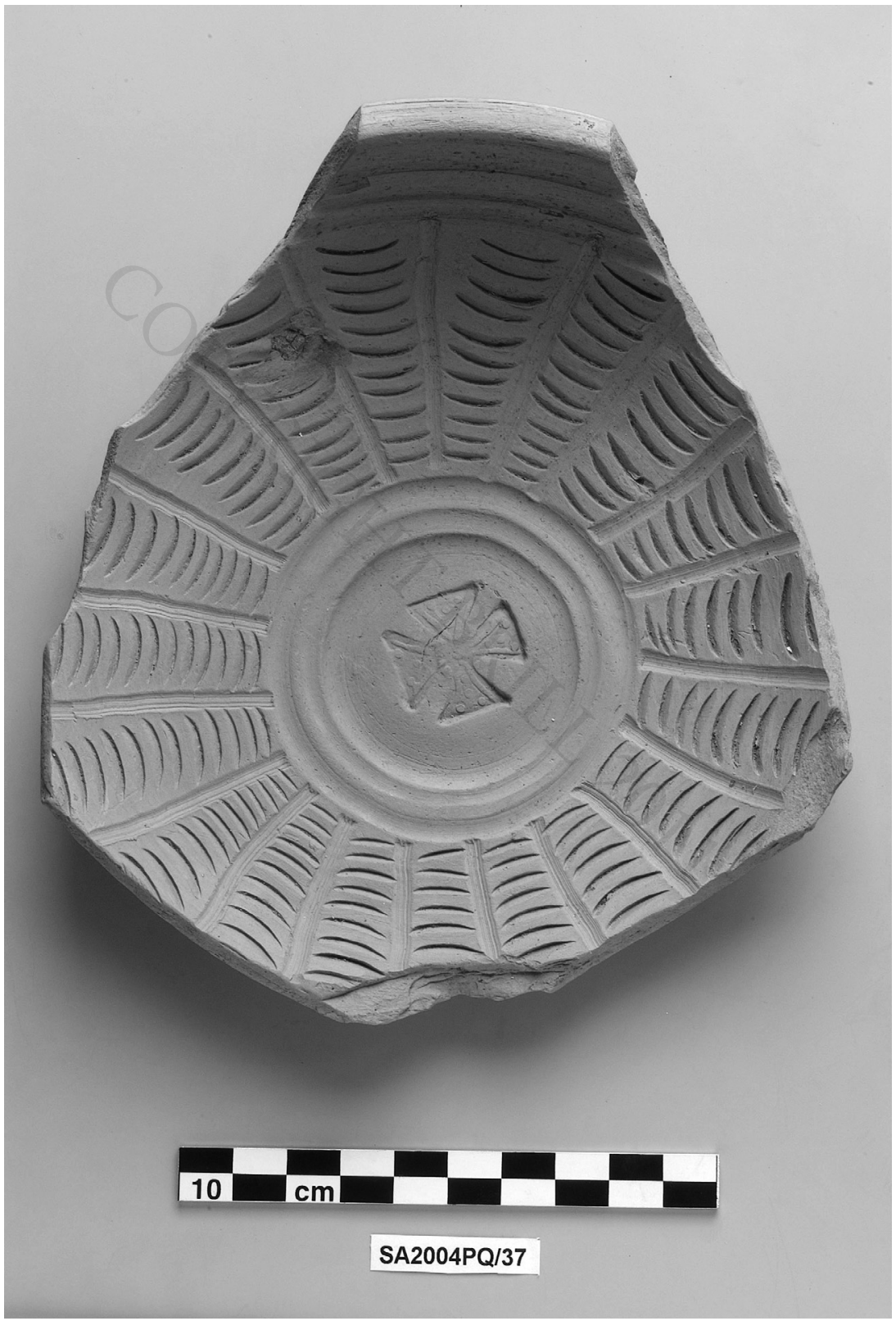

Fig. 5a

Fig. $5 \mathrm{a}-\mathrm{c}$ Christian symbols and scenes on Sagalassos Red Slip Ware: a) Mould for an oinophoros decorated with a Greek cross, found at the Potters' Quarter (SA2004PQ/37) and dated to the 5th to 6th c. (Sagalassos archive) 


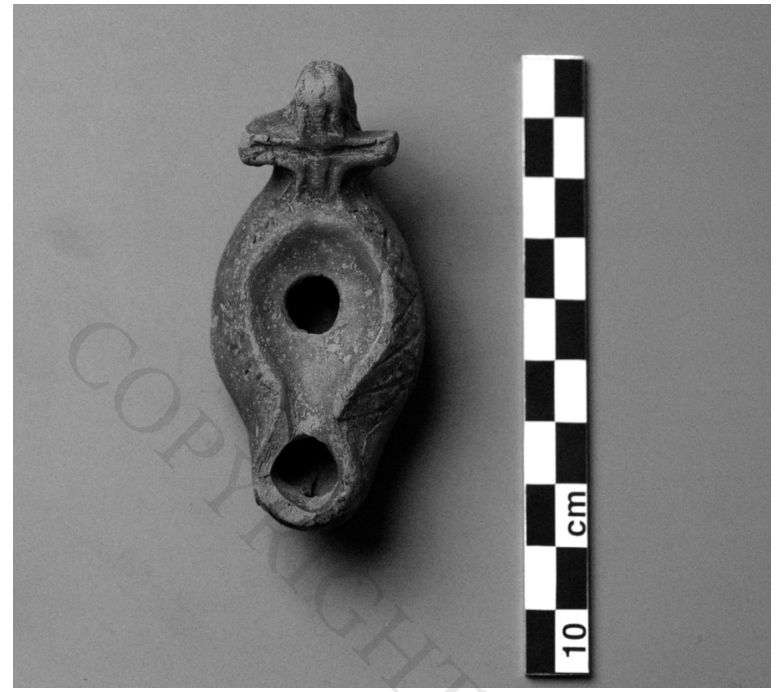

Fig. $5 b$

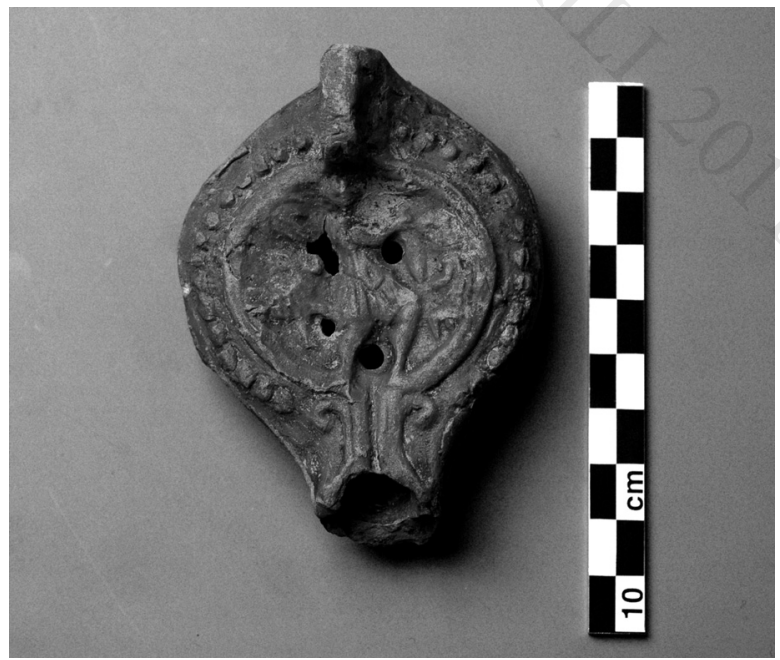

Fig. 5c

Fig. 5a-c Christian symbols and scenes on Sagalassos Red Slip Ware: b) oil lamp with a cross-shaped handle, found at the market building to the north of the Upper Agora (SA1994UAN/174) and dated to the 5th to 6th c. (Sagalassos archive); c) oil lamp displaying the sacrifice of Isaac, found on the Upper Agora (inv. no. SA1996UA/135) and dated to the 5th to 6th c.

(Sagalassos archive). 
buckles) and elements of jewellery (pendants, cameos and signet rings) as numerous instances from Sagalassos and Cilician Anemurium demonstrate. ${ }^{27}$ The Old Testament scenes present on 4th c. African Red Slip Ware persisted and now became widespread throughout the eastern Mediterranean as exemplified at Sagalassos (fig. 5c). But now Christian typological iconography also included New Testament themes, with a cycle of narrative scenes from Christ's ministry and passion, as well as images and items related to the cult of saints. ${ }^{28}$ This new Christian symbolism, particularly as depicted on artefacts for domestic use, took the cause of Christianisation beyond the monumental programmes of the churches into the homes of the faithful.

Yet this shift did not mark a complete break with traditional pagan iconography. Alongside the distinctively Christian images that now appeared, the new Christian iconography also incorporated, and at the same time reinterpreted, themes from the pagan past. The Christian converts of the late 4 th to early 5 th $\mathrm{c}$. came from a rich material culture which many preferred to adapt rather than abandon. This translated itself in the incorporation of the pagan past into the artistic or material production of the emerging Church, and resulted in what we have termed 'residual iconography'. Three significant instances of such adaptation attested in Sagalassos concern the goddess of Victory, Nike, the Mother Goddess and once again the cult of Dionysus. The iconographical type of Nike gave form to a divine concept shared by pagans and Christians alike, the angel, and developed its canonical winged form in the 5 th c. ${ }^{29}$ As we have seen, statues and other images of Nike remained popular in Sagalassos and the derived image of a winged figure holding a wreath is also present on oinophoroi from this period (fig. 6). ${ }^{30}$ The cult of angels was widespread throughout Asia

${ }^{27}$ Waelkens and Talloen (in press); Russell (1982).

${ }^{28}$ Christ's ministry and passion: Herrmann and van den Hoek (2002) 47-50. Cult of saints: One category of material culture in particular stands out, the so-called ampullae or miniature flasks that served as Early Christian souvenirs, holding holy substances such as blessed oil, water, soil etc. The examples from Egypt are especially famous, notably the so-called 'Menas flasks' from the pilgrim centre of the saint at Abu Mina, which date to the 5th-6th c. A.D.: Bangert (forthcoming). But there are similar types known from Asia Minor which feature saints or Biblical figures: Anderson (2004). Their appearance in the 5th c. corresponds to a popular surge in pilgrimages to Christian sites and to the homes of holy men.

${ }^{29}$ Podskalsky and Cutler (1991) 97; Kazhdan and Cutler (1991) 1475.

${ }^{30}$ On the continuing presence of Nike in the cityscape of late antique Ephesus, see Thür (2003) 270. 


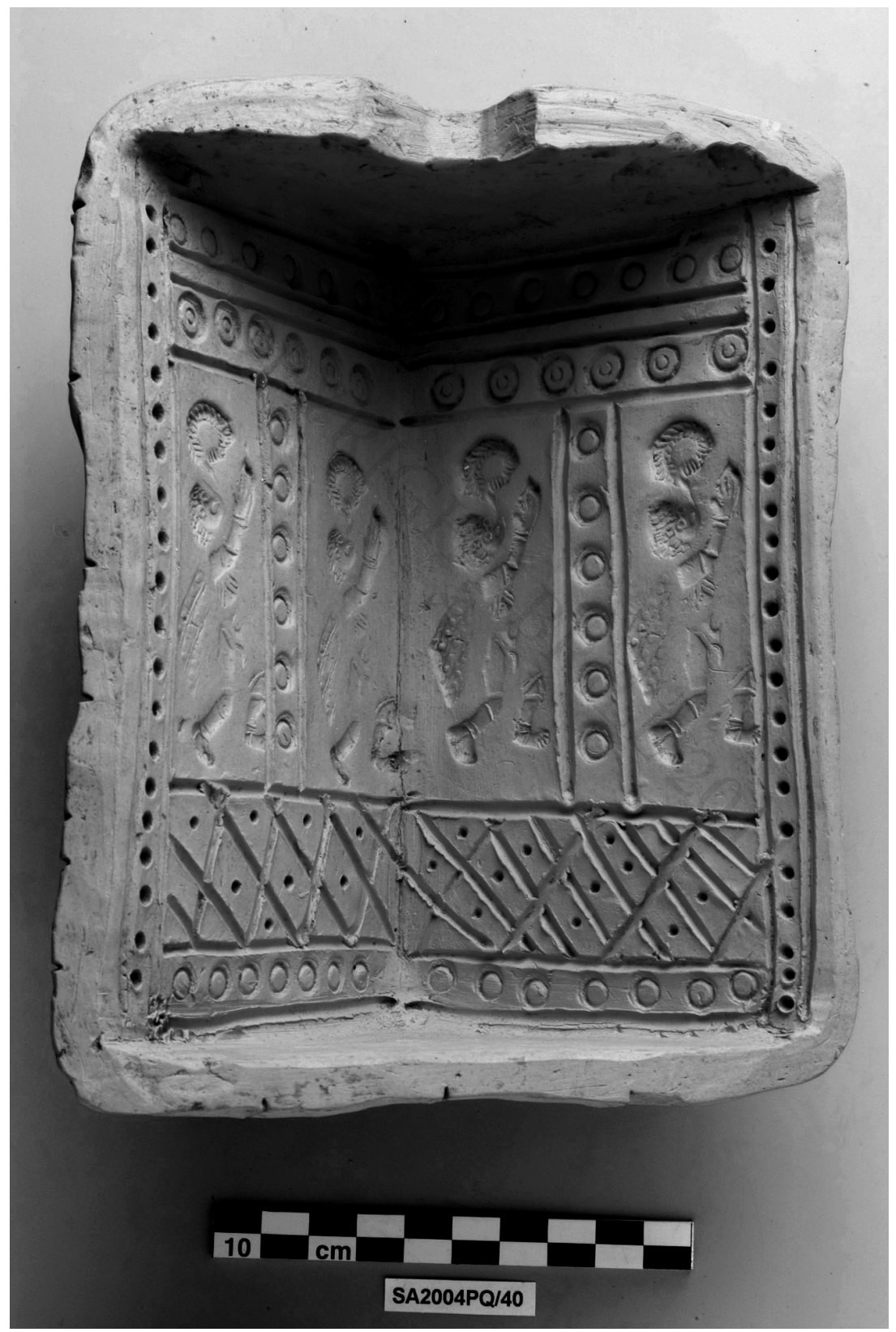

Fig. 6 Mould for a tetragonal oinophoros representing a flying winged Nike holding a wreath, found at the Potters' Quarter (SA2004PQ/40) and dated to the late 5 th to early 6 th c. (Sagalassos archive). 
Minor. That of Saint Michael the Archangel in particular seems to have taken an important place in the religious environment of Sagalassos during the 5th and 6th c., as indicated by several plates carrying acclamations of the Michaelitai, the followers of the Archangel. ${ }^{31}$

The Theotokos (bearer of God) image of the seated Virgin Mary with child, in its turn, is a continuation of the popular mother-theme represented by goddesses like Isis, Aphrodite and other kourotrophoi. ${ }^{32}$ The epiphany of a divine child would become one of Christianity's most significant iconographic forms. Some of the earliest Virgin and child imagery comes from Egypt in this period. Yet, this type was also very common elsewhere in the eastern Mediterranean, as illustrated by an ampulla - a small flask for sanctified oil or water - from Sagalassos depicting the adoratio of the infant Jesus by one of the Magi (fig. 7). ${ }^{33}$ Interestingly, towards the right of the main scene, there is a bust of Dionysus.

The continuing prominence of Dionysus in material culture from Sagalassos is also reflected in Christian artefacts. We already mentioned his presence in a Christian adoratio scene. It is uncertain whether the bust is present here as a remnant of the past or as an element of the present religious landscape, although it was in this period that the architectural elements from Dionysus' temple in Sagalassos were reused in the construction of the city's largest basilica (BE1), where the reliefs of satyrs and silens remained visible. ${ }^{34}$ Attributes of the Dionysiac cult such as the vine and the kantharos were adopted into Christian eucharistic symbolism, with the frequent appearance of vine scrolls in Christian art recalling the words of Christ, 'I am the true vine' (John 15:1). ${ }^{35}$ A late 5th to early 6th c. hexagonal oinophoros from Sagalassos, featuring a stylised depiction of the Eucharist, with a cross on top of a globe placed underneath the ciborium and surrounded by vines and loaves of bread, is a fine example of the adoption of such imagery (fig. 8).

A further example of residual iconography from Sagalassos is provided by the 'divine rider'. Excavations throughout the city have

31 Waelkens and Talloen (in press).

32 Elsner (1998) 220-21.

33 Hayes (1997) 88 pl. 36. The origin of this piece, kept at the British Museum (inv. no. MLA 1882.1-9.1), is reported as unknown but could be identified as from Sagalassos by the author on the basis of the type and some of the used decorative elements.

34 Waelkens and Talloen (in press). See also the contribution of Talloen and Vercauteren on the fate of temples in Asia Minor in this volume.

35 Buckton (1994) 39-40; Elsner (1998) 100, 153. 


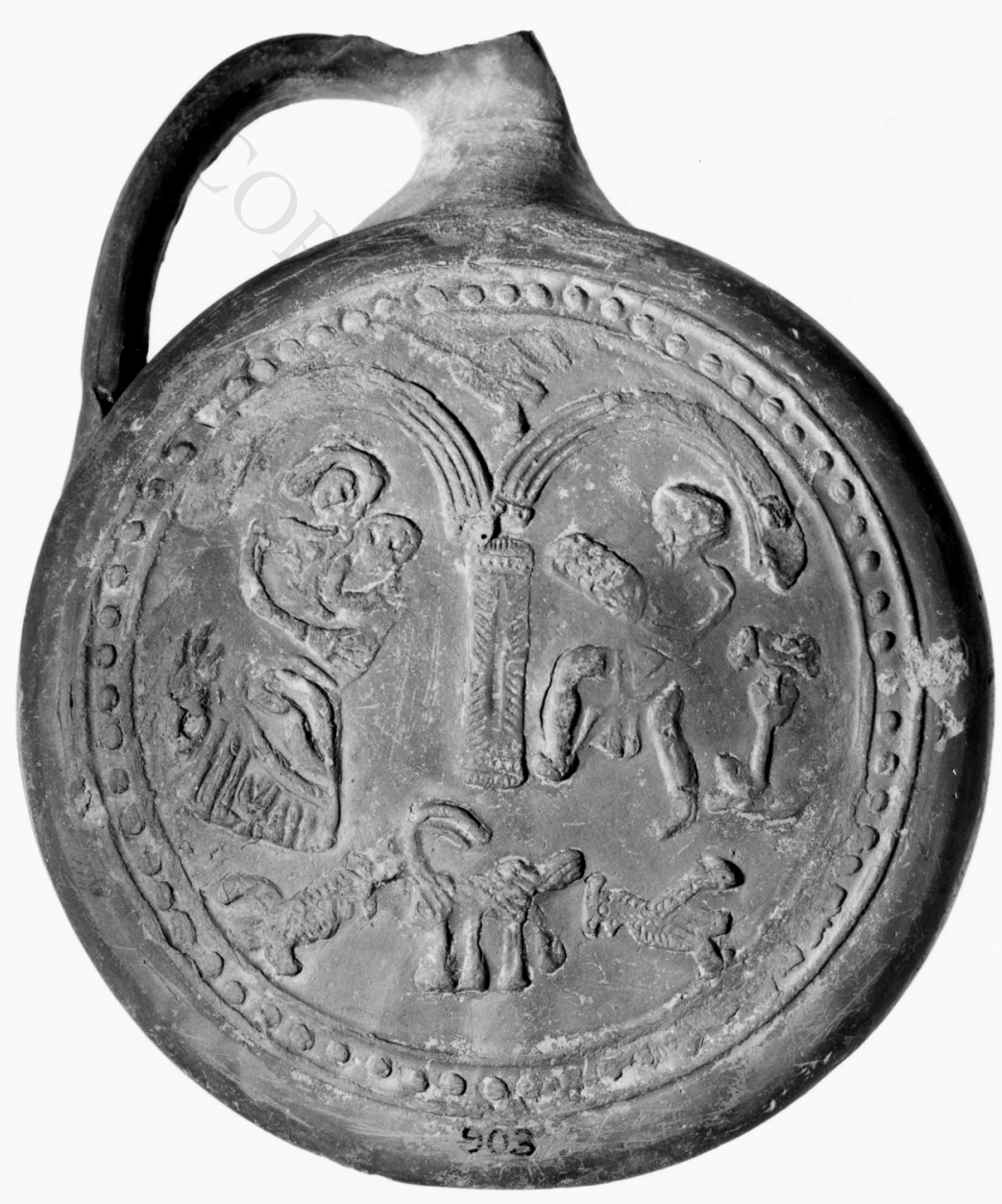

Fig. 7 Ampulla with an adoratio scene from Sagalassos, kept at the British Museum (inv. no. MLA 1882.1-9.1) where it was brought from an unknown location in Asia Minor, and dated to the late 5th c. (Hayes (1997) 88 pl. 36). 


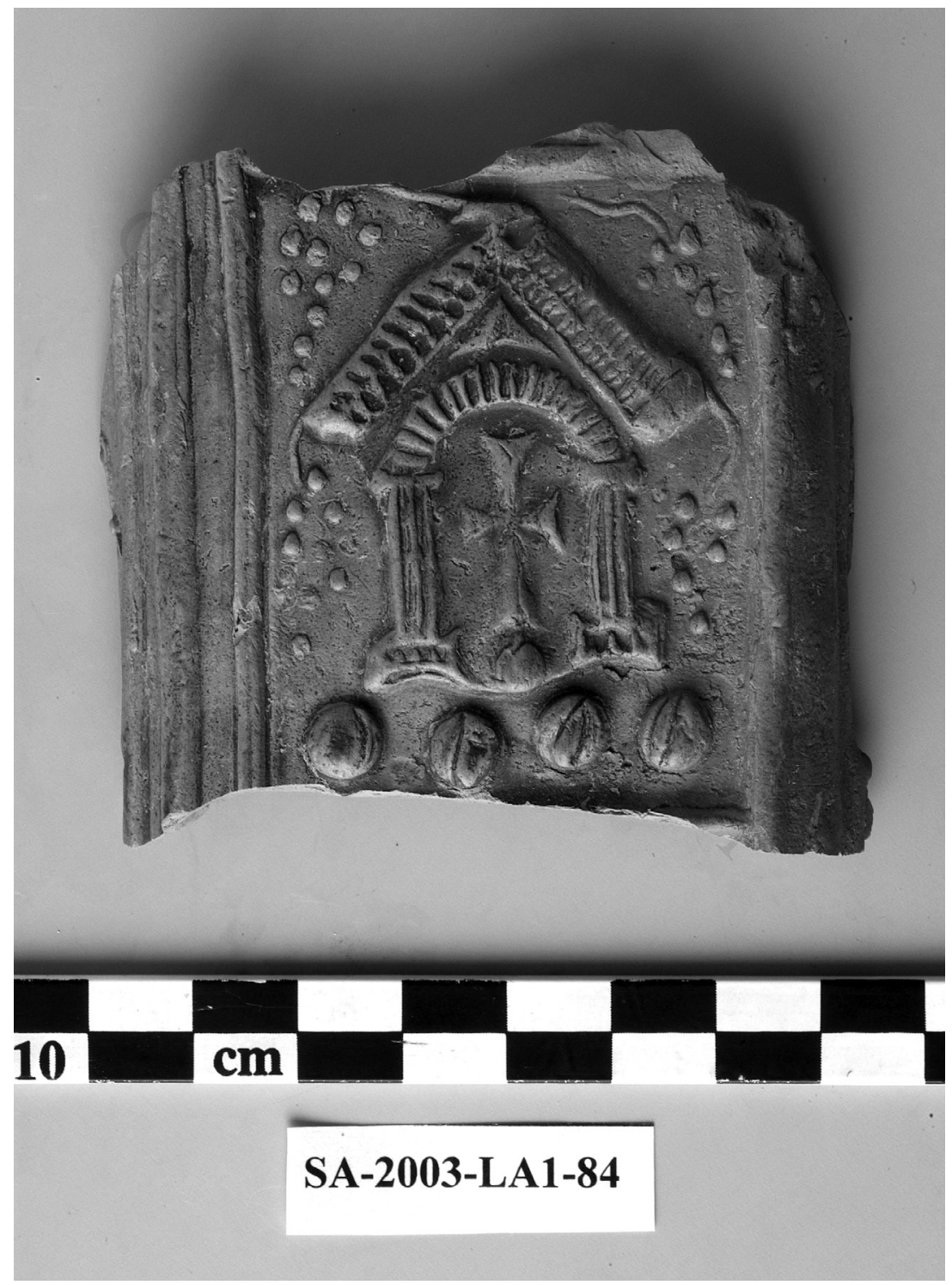

Fig. 8 Fragment of a hexagonal oinophoros with a stylised representation of the Eucharist, found on the Lower Agora (SA2003LA1/84) and dated to the late 5 th to early 6 th c. (Sagalassos archive). 
unearthed a series of warrior figurines on horseback that appear to date to the late 5 th to early 6 th c. (fig. 9). Previously erroneously identified as images of the indigenous rider god Kakasbos, these terracotta figurines are not to be seen as a late antique revival of paganism or a popular continuation of an ancient local cult, for explicitly Christian figurines are present in the same stratigraphical contexts. ${ }^{36}$ The latter represent a bearded male figure wearing a mitre decorated with a cross, which appears to identify the man as a Christian priest or perhaps even a saint (fig. 10). This type can be associated both chronologically and typologically with the warrior figurines since the spread legs of these priest figures indicate that they too were seated on horseback. Moreover, locally manufactured terracotta masks from the 6th c. also depict the same warrior figures, and the illegible inscription on one such mask was preceded by a cross (fig. 11). We are therefore dealing here with Christian images and can argue that the terracotta figurines represent Christian military saints. ${ }^{37}$ These rider saints may again be seen as a continuation of long-standing pagan iconography and the descendants of the indigenous rider deities who offered protection in earlier times. ${ }^{38}$

The terracotta figurines not only illustrate the adaptation of pagan imagery for Christian use but also the continuation of the production and use of terracotta figurines themselves, far beyond the point of their alleged demise. It is traditionally held that the production of these artefacts began to decline from the 3rd c. onwards and disappeared entirely by the 5 th c. ${ }^{39}$ This decline was allegedly due to the triumph of Christianity, for the craft of terracotta was 'too deeply rooted in paganism' to survive. ${ }^{40}$ Yet for the vast majority of the population, conversion to Christianity could not have meant the total abandonment of all aspects of their earlier lives. Rather than a complete change, it represented a coalescence of practices, in which some long-standing

\footnotetext{
${ }^{36}$ Kakasbos: Waelkens (1993) 45.

37 Rider figurines have also been found in 6th c. Christian contexts in Egypt, as at the shrine of Saint Menas where they have been interpreted as pilgrim artefacts: Bangert (forthcoming).

${ }_{38}$ Talloen and Poblome (2005) 73-77. Elsewhere in south-western Asia Minor, two riders on horseback sounding trumpets on either side of an inscribed Maltese Cross are depicted on the door lintel of a church in northern Lycia. As this arrangement precisely imitates local reliefs of the mounted Dioskouroi on either side of a veiled goddess, this too can be seen as a Christian reinterpretation of the rider motif: Talloen (2006) 753 .

${ }_{39}$ Higgings (1986) 64; Thompson and Vickers (2003) 1486.

40 Chesterman (1974) 76; Higgins (1976) 105.
} 


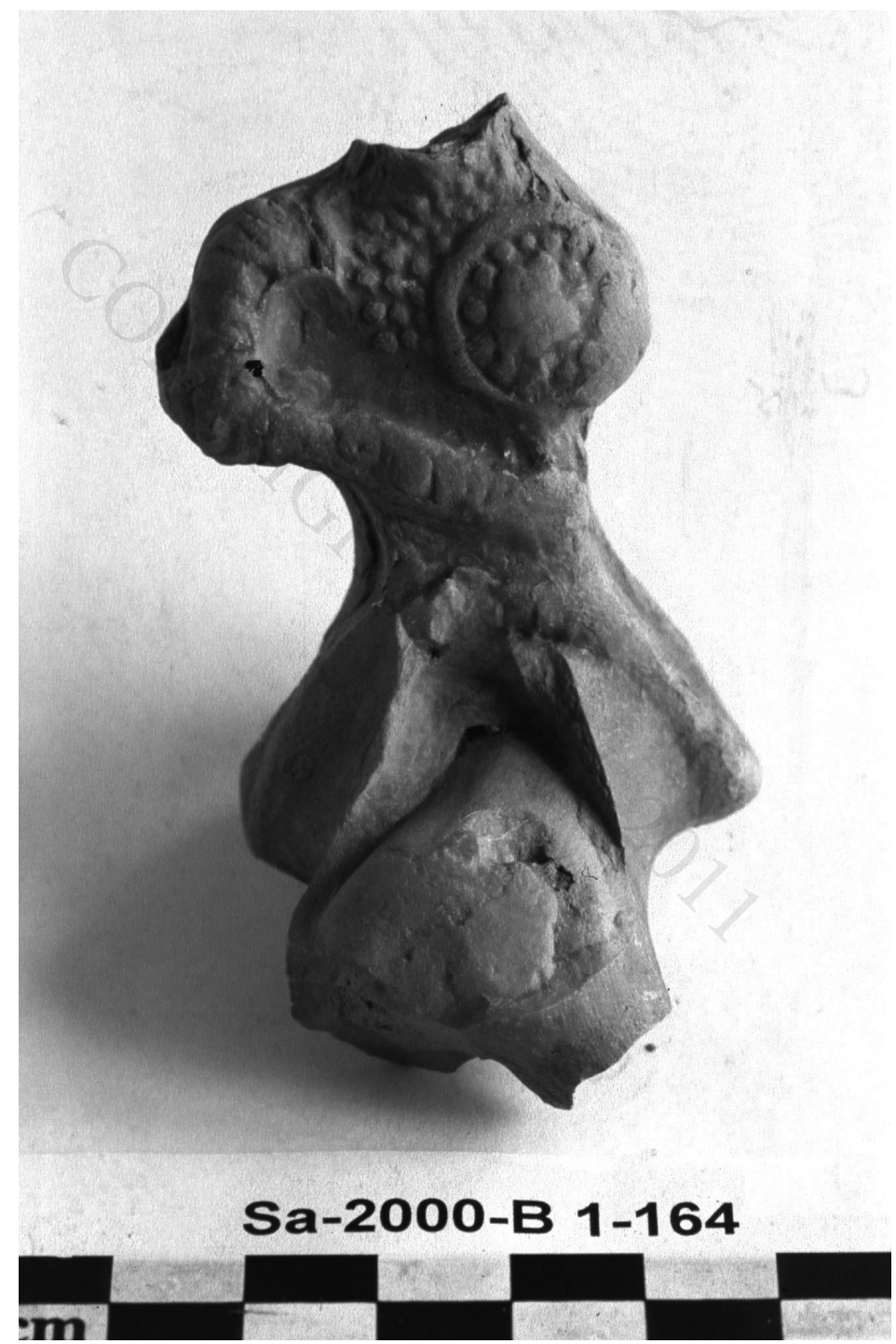

Fig. 9 Terracotta figurine of a warrior on horseback (inv. no. SA2000B1/164), found at the Bouleuterion and dated to the late 5th to early 6th c. (Sagalassos archive). 


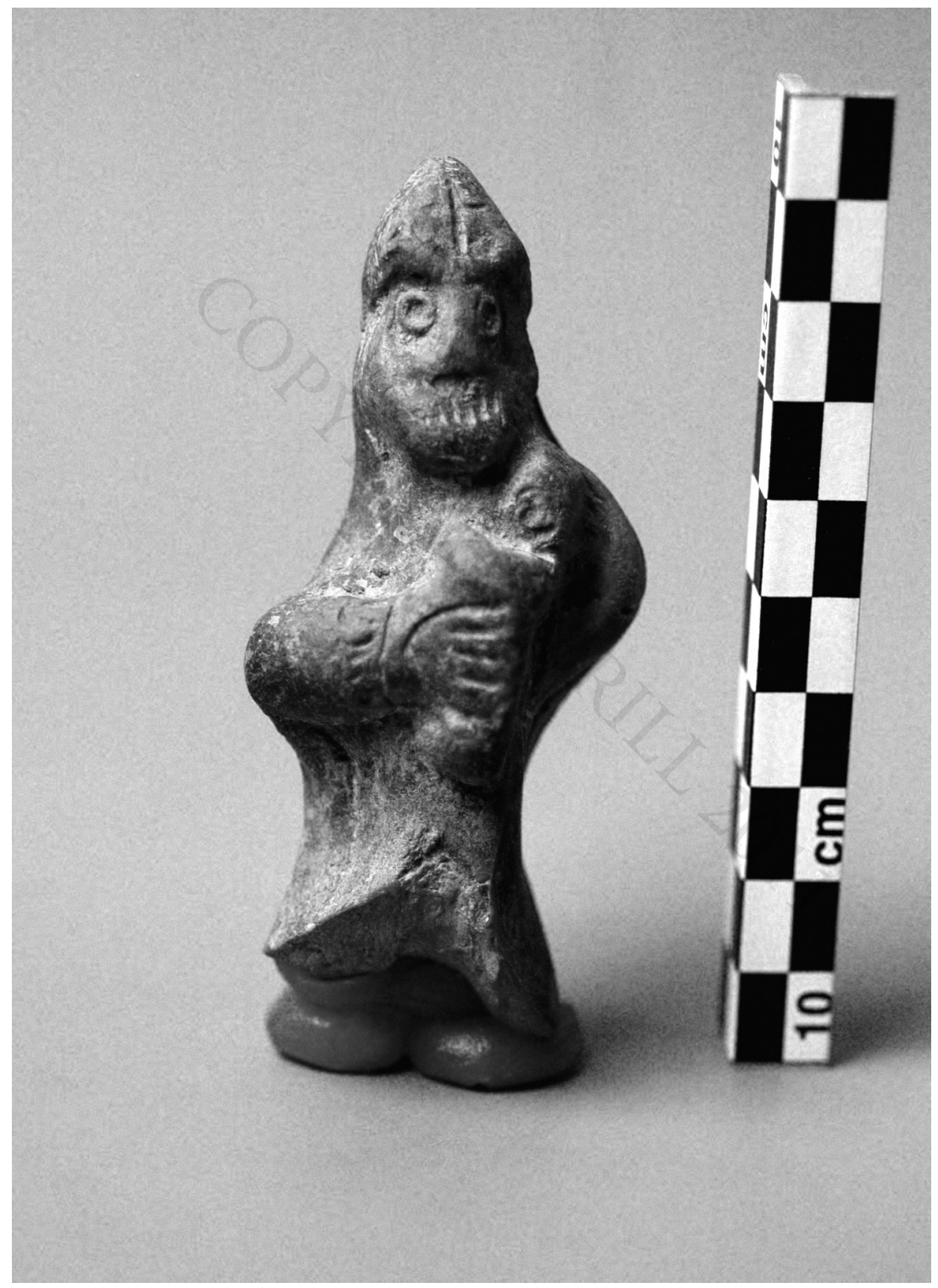

Fig. 10 Terracotta figurine of a Christian priest or saint (on horseback) found at the Doric Temple (inv. no. SA1991DT/347) and dated to the late 5 th to early 6th c. (Sagalassos archive). 


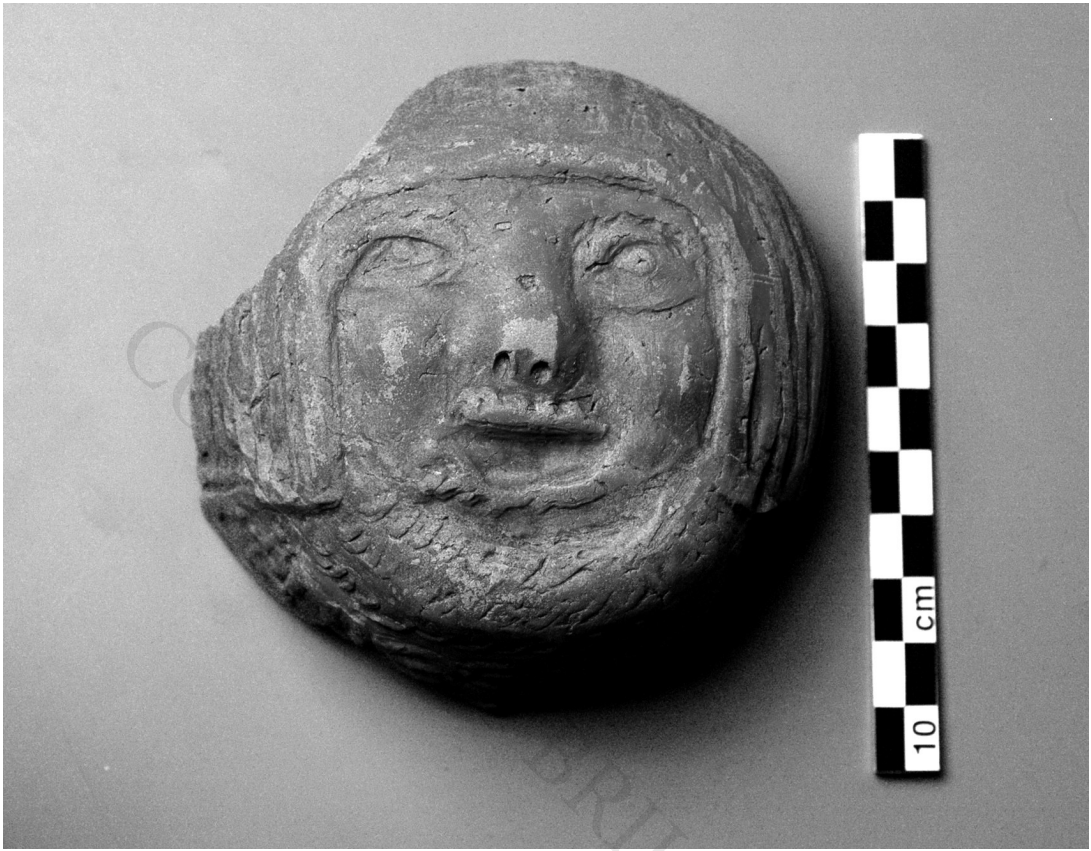

Fig. 11 Terracotta mask representing a helmeted warrior, found on the Lower Agora (inv. no. SA2003LA1/79) and dated to the 6th c. (Sagalassos archive).

local traditions continued in new forms. ${ }^{41}$ The terracotta figurines of Sagalassos comprise not only the aforementioned rider statuettes but also numerous representations of dogs and horses, whose ongoing use in a Christian context is exemplified by the representation of an unidentified animal with a cross incised on its back (fig. 12). Such figures most probably served as offerings, perhaps as representations of the animals for which protection was invoked. ${ }^{42}$

Despite the hostility of a number of Christian writers, magical practices common among Graeco-Roman pagans also continued little changed under Christianity. People maintained their superstitious belief in the unseen power of the Evil Eye to wreak havoc on people's lives, and in the need to apply instruments to counter its malign

${ }^{41}$ Whitby (1991) 114. On the adoption of 'pagan' rites in Christianity see MacMullen (1997) 103-49. Whether it is true, as if often assumed, that aristocratic circles held on longer to pagan customs and material culture is an important question, but lies beyond the scope of this paper.

${ }^{42}$ For the offering of animals as ex-votos at Christian shrines, see Zwirn (1999) 440. 


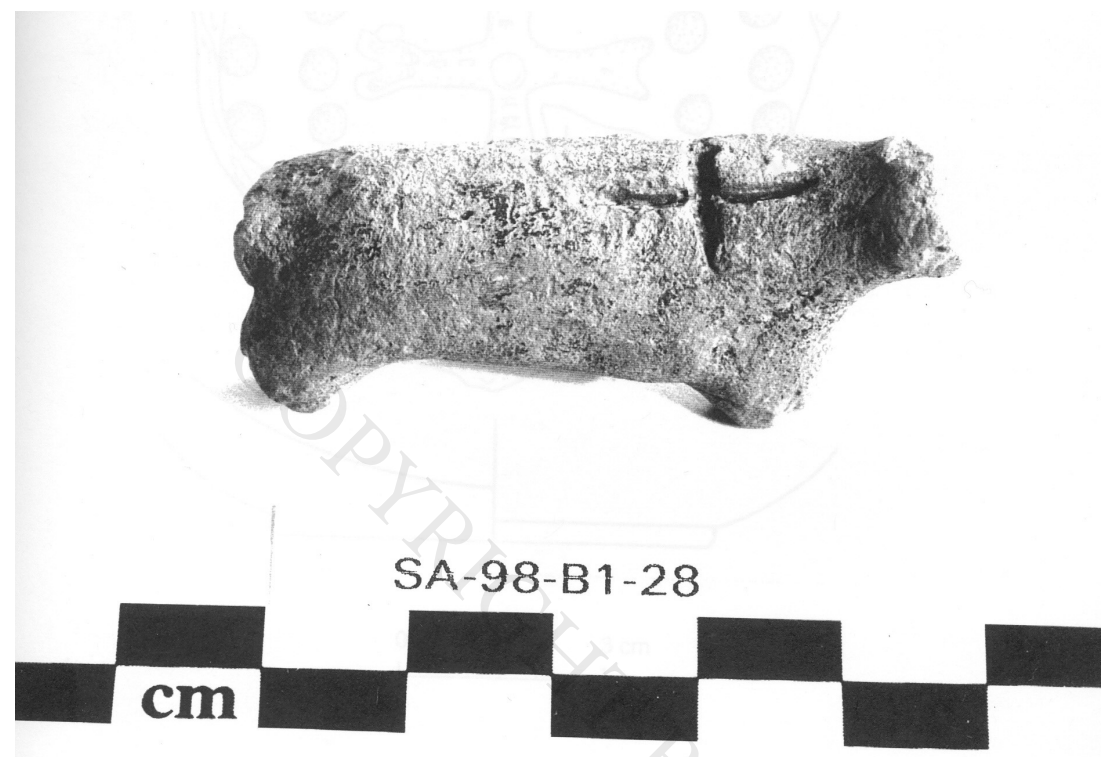

Fig. 12 Terracotta figurine of an unidentified four-legged animal with a cross incised on its back, found at the Bouleuterion (inv. no. SA1998B1/28) and dated to the late 5 th to early 6 th c. (Sagalassos archive).

influence. ${ }^{43}$ This may account for the considerable number of small bronze bells or tintinnabula which have been found at city sites throughout the eastern Mediterranean (fig. 13). These objects were used as apotropaic devices above cradles to protect infants or suspended from doorways to secure the entrance to the home, and were as much a part of everyday late antique life as the cooking pot. ${ }^{44}$

Finds from Sagalassos also include a series of 6th c. A.D. medallions carrying the effigy of King Solomon of a type which was widespread in the eastern Mediterranean in this period (fig. 14). ${ }^{45}$ Solomon is depicted as a nimbate horseman in military dress, striking down a prostrate female demon. The holy rider - the generic emblem of good conquering evil — was an especially popular image with pre-Christian roots. ${ }^{46}$ The motif is well-attested not only on amulets but also on

${ }^{43}$ On the use of magic in late antique Christianity, see MacMullen (1997) 140-43.

${ }^{44}$ Russell (1995) 42-45.

${ }^{45}$ Russell (1995) 40.

${ }^{46}$ Vikan (1991) 82. 


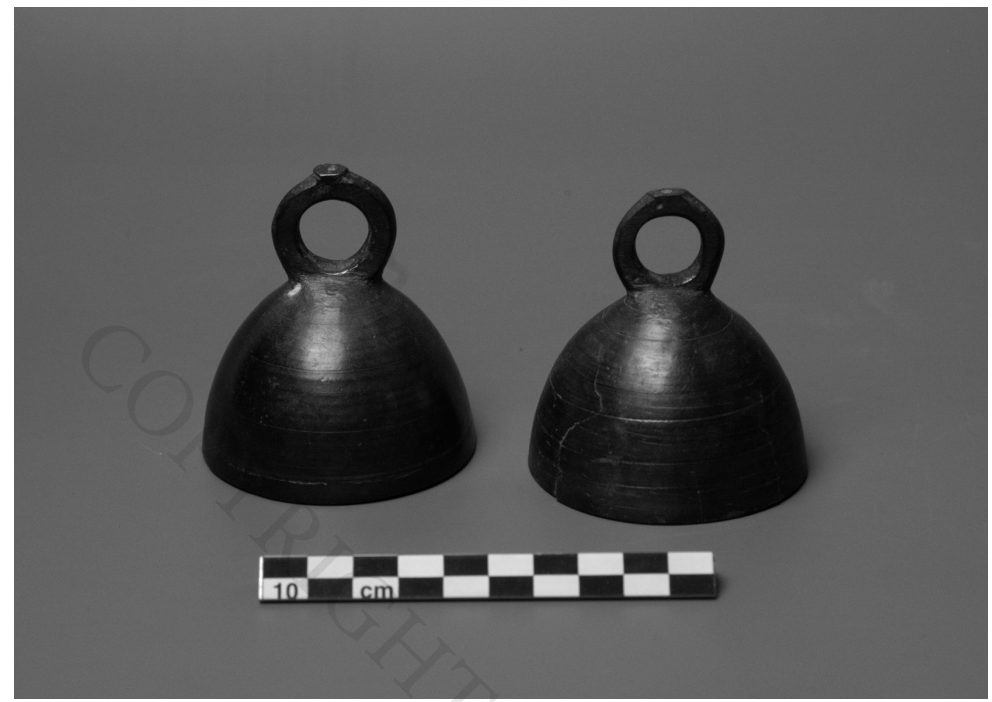

Fig. 13 Two Tintinnabula or bronze bells, found at the Doric Fountain House (SA1991N/577) and dated to the 5th to 6th c. (Sagalassos archive).

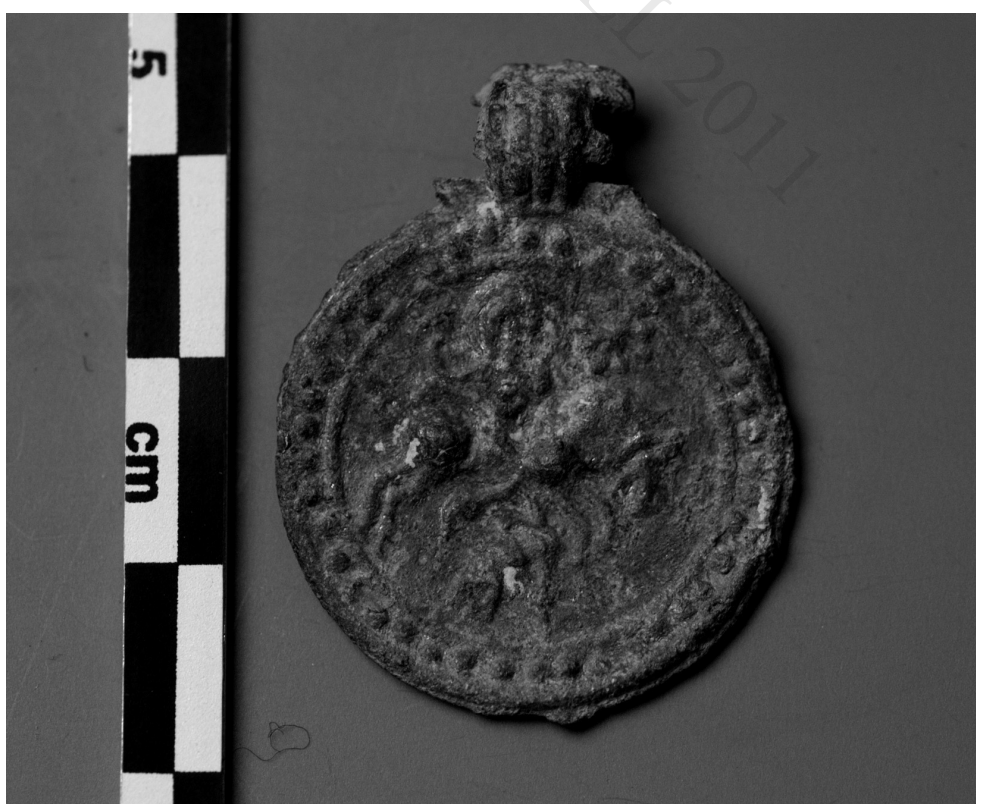

Fig. 14 Leaded bronze medallion representing Solomon on horseback striking down a prostrate female demon, found at the market building to the north of the Upper Agora (SA1995UAN/159) and dated to the 6th c. (Sagalassos archive). 
rings, incised gemstones and bracelets. According to the Testamentum Solomonis, one of the most popular late antique magical treatises, Solomon was able to control evil forces through a seal ring given to him by God with which he could 'lock up all the demons' ${ }^{47}$ The Sagalassos amulets were intended to protect their bearers with the same magical power as the original seal.

\section{From the Later 6th Century to the Mid 7th Century: the Last Degades of Sagalassos}

From the later 6th c. onwards, we witness the disappearance of pagan elements in the iconography of household items from Sagalassos with terracotta figurines ceasing to exist. ${ }^{48}$ Explicit Christian motifs take over, completely dominating the material culture of daily life, from pottery to articles of adornment. The last phase of pottery production at Sagalassos from A.D. 550 to 650 is completely devoid of pagan imagery such as the Dionysiaca. ${ }^{49}$ The oinophoroi now depict neutral images such as hunting scenes, graphic motifs and doves on a kantharos (fig. 15), while the decoration of other types of ceramic vessels is limited to stamped crosses. The mythological subjects that had lingered on in the private sphere on silver plate similarly disappear by the mid-7th c. A.D. and the utensils (and even food) used in dining were now culturally imbued with intimations of the Last Supper and the Eucharist or Biblical scenes, such as the David plates. ${ }^{50}$

Sacred imagery was thus employed at a domestic level to support the principal religious and temporal institutions of Christian society. The establishment of canonical Christianity led in the visual arts to the slow creation of a canonical iconography for Christian imagery which had no place for pagan motifs. ${ }^{51}$ This transition from an older and more diverse culture towards a firmly Christian society, along with the gradual disappearance of residual pagan iconography in the

\footnotetext{
${ }^{47}$ McCown (1922).

${ }^{48}$ Pagan iconography also disappears at other pottery production centres, for instance at Athens: Karivieri (2001) 196. Figurines also disappear in Egypt at this time: Bangert (forthcoming).

${ }^{49}$ The common image of Dionysus disappears from art after the 6th c., only to return in the 11th c., with the sole purpose of illustrating the homilies of Gregory of Nazianzos (Kazhdan, Gutler and Talbot (1991) 631.

${ }^{50}$ Buckton (1994) 13; Elsner (1995) 253, 266-70.

${ }^{51}$ Elsner (1998) 223.
} 


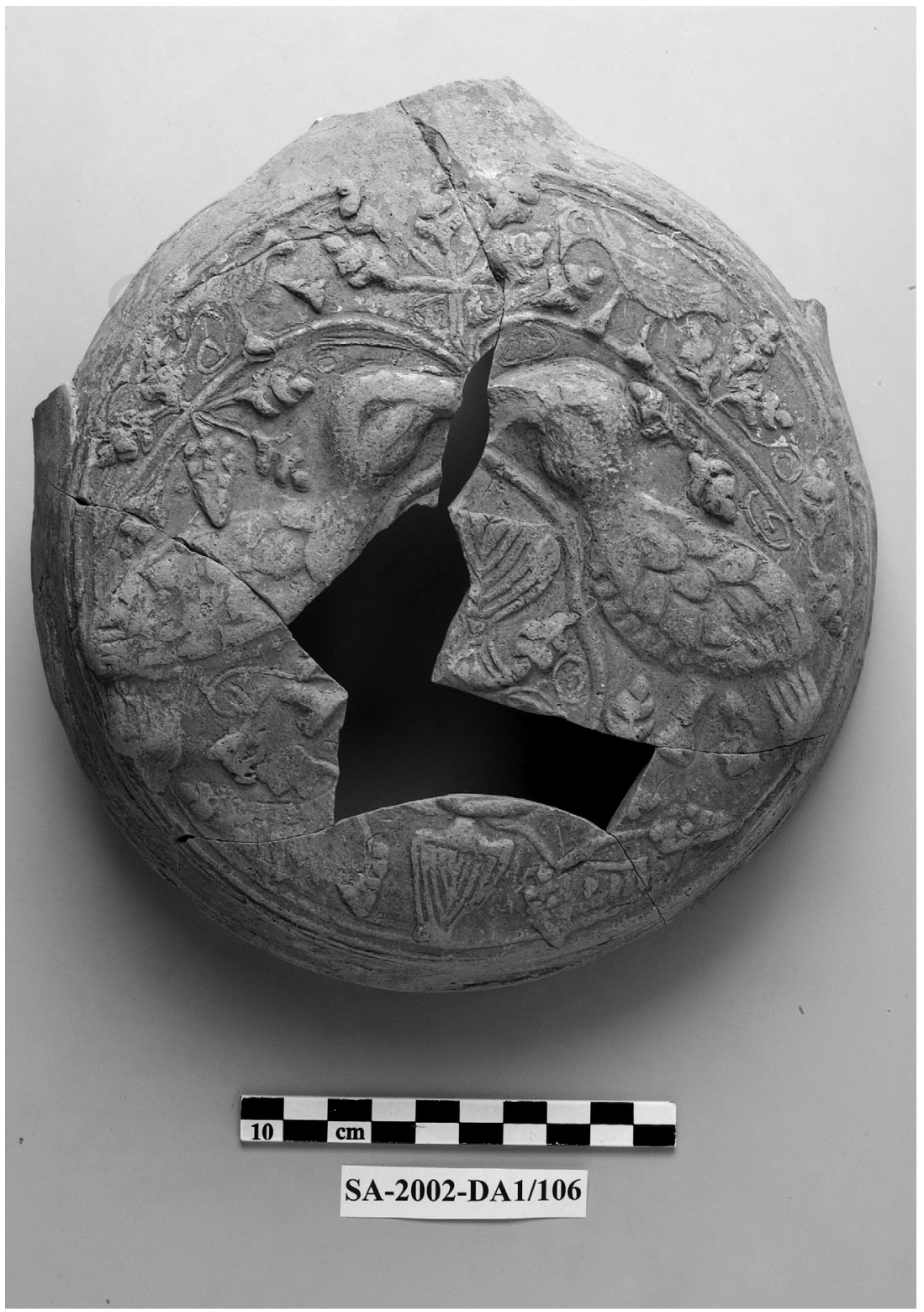

Fig. 15 Oinophoros depicting two doves flanking a central kantharos, found at the Domestic Area (inv no. SA2002DA1/106) and dated to the late 6th to 7th c. (Sagalassos archive). 
course of the 6th c. A.D., can perhaps be explained by what Robert Markus has described as the shift from 'ancient' to 'medieval' Christianity. ${ }^{52}$ The efforts of the emperor Justinian to impose uniformity of culture, religion and law on an orthodox Christian empire may also have played a role. ${ }^{53}$ But whatever the cause, by the 7 th c. in Sagalassos, as elsewhere, the earlier fusion of Christianity and classical traditions had gone, to be replaced by a simpler and more universally Christian material culture.

\section{Conclusion}

This short survey of the domestic material culture of Sagalassos from the 4th to the 7th c. highlights once again the religious complexity of late antique society. Paganism and Christianity coexisted in the lives of many, and conversion was not always a straightforward sequential experience of moving from one set of beliefs to another. Yet the late antique period witnessed the gradual transformation of the Roman empire into a Christian empire. The instrumentarium domesticum that has been examined here offers a largely neglected means to trace this transformation and to study the interaction of pagan and Christian images and practices within the daily lives of the inhabitants of an important, but by no means exceptional, late antique city.

During the 4th c. Christian iconography, known above all from the Roman catacombs, had no parallel in wider material culture, which continued to be dominated by the pagan tradition. Secular, pagan and Jewish images were adapted to Christian purposes, but symbols or words attesting explicitly to Christian identity are lacking, perhaps because the Christian communities in the East were still simply too few in numbers to produce a dominant visible culture. It was only once Christianity was thrust into the role of religion of the empire that mass-produced goods proclaiming Christian identity followed. This recognition of Christianity as the official religion of the Roman empire at the end of the 4th c. affected people's need for art and material culture as individuals acquired a new Christian identity. It does not necessarily follow that all those who owned or used these

${ }^{52}$ Markus (1990).

${ }^{53}$ Whitby (1991); Maas (2000) 20-21. 
Christianised artefacts were themselves Christian, but the appearance of such items must be indicative of a profound religious change in society. The prominence of religiously charged symbols such as fishes and crosses, as well as Biblical scenes on decorated pottery from the late 4th c. suggests an active religious message rather than ornamentation, as does the contrasting emphasis on Dionysiac imagery on Sagalassos pottery wares in the same period.

In the 5th c., the expansion of Christian material culture did not mark a complete break with traditional pagan iconography or practice. Older pagan prototypes were reinterpreted to serve Christian ends, a process particularly visible through the domestic wares and terracotta figurines of Sagalassos, which reflect the continuing use of existing images and customs in the daily lives of both pagans and newly converted Christians. The Church may have defeated the gods but it had not defeated the force of religious habit in its own congregation, habits taken directly from the non-Christian past. It was therefore inevitable that Christianity would be influenced by the pagan culture it was trying to convert, and, as suggested by Elsner, some within early Christianity may well have tried to make their faith accessible through these assimilations with paganism. ${ }^{54}$

It is rarely possible to determine whether the surviving images of pagan deities such as Dionysus are expressions of actual religious belief, but pagan worship certainly continued throughout the 5th $\mathrm{c}$. in many cities of the eastern Mediterranean, and it is tempting to see this survival reflected, at least in part, in the residual iconography. By the 6th and 7th c., these openly pagan scenes had disappeared. Christian motifs and iconography now dominated the material culture, with older symbols 'subsumed into a Christian religious dispensation' as part of the shift to a fully Christian empire. ${ }^{55}$

The late antique transformation of the pagan Graeco-Roman world into a Christian empire stands as one of the most radical cultural revolutions in world history, yet it did not necessarily seem so at the time. The evidence from Sagalassos surveyed here provides a further reminder of the many elements of continuity that facilitated the transformation, and of the adaptation of Christianity to local circumstances

\footnotetext{
54 Elsner (1998) 220.

55 Elsner (1998) 51.
} 
and indigenous religious customs. The study of the domestic material culture of a single city or region thus offers insights into the religious mentality of the late antique world, which aids us in better understanding the final stages of paganism and its heritage in the formation of early Christianity.

\section{BIBLIOGRAPHY}

Akerström-Hougen G. (1974) The Calendar and Hunting Mosaics of the Villa of the Falconer in Argos: A Study in Early Byzantine Iconography (Skrifter utgivna av Svenska Institutet i Athen 4.33) (Stockholm 1974).

Anderson W. (2004) "An archaeology of late antique pilgrim flasks", AnatSt 54 (2004) 79-93.

Bangert S. (2010) The archaeology of pilgrimage: Abu Mina and beyond, in Religious Diversity in Late Antiquity, edd. D. Gwynn and S. Bangert (Late Antique Archaeology 6) (Leiden and Boston 2010) 293-327.

Bayliss R. (2004) Provincial Cilicia and the Archaeology of Temple Conversion (BAR-IS 1281) (Oxford 2004).

Bowersock G. W. (1990) Hellenism in Late Antiquity (Thomas Spencer Jerome Lectures 18) (Ann Arbor 1990).

Buckton D. (1994) ed. Byzantium: Treasures of Byzantine Art and Culture from British Collections (London 1994).

Caseau B. (1999) "Sacred landscapes", in Late Antiquity. A Guide to the Postclassical World, edd. G. W. Bowersock, P. Brown and O. Grabar (Cambridge, Mass. and London 1999) 21-59.

Castrén P. (1999) "Paganism and Christianity in Athens and vicinity during the fourth to sixth centuries AD", in The Idea and Ideal of the Town between Late Antiquity and the Early Middle Ages, edd. G. P. Brogiolo and B. Ward-Perkins (The Transformation of the Roman World 4) (Leiden, Boston and Cologne 1999) 211-23.

Chesterman J. (1974) Classical Terracotta Figures (London 1974).

Dark K. (2004) ed. Secular Buildings and the Archaeology of Everyday Life in the Byzantine Empire (Oxford 2004).

Daszewski W. (1985) Dionysos der Erlöser. Griechische Mythen im spätantiken Zypern (Trierer Beiträge zur Altertumskunde 2) (Mainz 1985).

Elsner J. (1995) Art and the Roman Viewer. The Transformation of Art from the Pagan World to Christianity (Cambridge 1995).

- (1998) Imperial Rome and Christian Triumph. The Art of the Roman Empire A.D. 100400 (Oxford History of Art) (Oxford 1998).

- (2003) "Archaeologies and agendas. Reflections on late ancient Jewish art and Early Christian art”, $\mathcal{J} R S 93$ (2003) 114-28.

Garbsch J. and B. Overbeck (1989) Spätantike zwischen Heidentum und Christentum (Munich 1989)

Hanfmann G. M. A. and H. Buchwald (1983) "Christianity: churches and cemeteries", in Sardis from Prehistoric to Roman Times: Results of the Archaeological Exploration of Sardis 1958-1975, edd. G. M. A. Hanfmann and W. E. Mierse (Cambridge, Mass 1983) $191-210$.

Hannestad N. (1994) Tradition in Late Antique Sculpture: Conservation, Modernization, Production (Acta Jutlandica 69.2) (Aarhus 1994). 
(2002) "Das Ende der antiken Idealstatue. Heidnische Skulptur in christliche Hausern", AntW 33.6 (2002) 635-49.

Harl K. W. (1990) "Sacrifice and pagan belief in fifth- and sixth-century Byzantium", PastPres 128 (1990) 7-27.

Hayes J. W. (1972) Late Roman Pottery (London 1972).

- (1997) Handbook of Mediterranean Roman Pottery (London 1997).

Herrmann J. J. and van den Hoek A. (2002) Light from the Age of Augustine. Late Antique Ceramics from North Africa (Tunisia) (Cambridge, Mass. 2002).

Higgins R. (1976) "Terracottas", in Roman Crafts, edd. D. Strong and D. Brown (London 1976) 105-109.

- (1986) Tanagra and the Figurines (Princeton, New Jersey 1986).

Huskinson J. (2004) "Surveying the scene: Antioch mosaic pavements as a source of historical evidence", in Culture and Society in Later Roman Antioch. Papers from a Colloquium London, 15th December 2001, edd. I. Sandwell and J. Huskinson (Oxford 2004) 134-52.

Jensen R. M. (2000) "Christian art", in The Early Christian World, vol. 2, ed. P. Esler (London 2000) 747-72.

Karivieri A. (2001) "Mythological subjects on Late Roman lamps and the persistence of classical tradition", in Late Antiquity: Art in Context, edd. J. Fleischer, J. Lund and M. Nielsen (Danish Studies in Classical Archaeology. Acta Hyperborea 8) (Copenhagen 2001) 179-98.

Kazhdan A. and Cutler A. (1991) "Nike", in The Oxford Dictionary of Byzantium, vol. 3, ed. A. Kazhdan (New York and Oxford 1991) 1475.

Kazhdan A., Cutler A. and Talbot A. M. (1991) "Dionysos", in The Oxford Dictionary of Byzantium, vol. 1, ed. A. Kazhdan (New York and Oxford 1991) 631-32.

Ladstätter S. and Sauer R. (2005) "Late Roman C-Ware und lokale spätantike Feinware aus Ephesos", in Spätantike und mittelalterliche Keramik aus Ephesos, ed. F. Krinzinger (Archäologische Forschungen 13) (Vienna 2005) 143-201.

Lanckoronski K. Graf von (1892) Städte Pamphyliens und Pisidiens, vol. 2. Pisidien (Vienna 1892).

Lund J. (2001) "Christian lamps. Motifs in context", in Late Antiquity: Art in Context, edd. J. Fleischer, J. Lund and M. Nielsen (Danish Studies in Classical Archaeology. Acta Hyperborea 8) (Copenhagen 2001) 199-214.

Maas M. (2000) "People and identity in Roman Antioch", in Antioch. The Lost Ancient City, ed. C. Kondoleon (Princeton, New Jersey 2000) 13-21.

MacCoull L. S. B. (1991) "Apollo", in The Oxford Dictionary of Byzantium, vol. 1, ed. A. Kazhdan vol. 1 (New York and Oxford 1991) 136-37.

MacMullen R. (1984) Christianizing the Roman Empire AD 100-400 (New Haven, Connecticut and London 1984).

_ (1997) Christianity and Paganism in the Fourth to Eight Centuries (New Haven, Connecticut and London 1984).

Maguire H. (1999) "The good life", in Late Antiquity. A Guide to the Postclassical World, edd. G. W. Bowersock, P. Brown and O. Grabar (Cambridge, Mass. and London 1999) 238-57.

Markus R. A. (1990) The End of Ancient Christianity (Cambridge 1990).

McGown C. C. (1922) The Testament of Solomon (Leipzig 1922).

Parrish D. (1995) "A mythological theme in the decoration of Late Roman dining rooms: Dionysos and his circle, $R A$ (1995) 307-32.

Poblome J. (1998) "Dionysiac oinophoroi from Sagalassos found in Egypt", in Egyptian Religion the Last Thousand Years, I. Studies Dedicated to the Memory of Jan Quaegebeur (Orientalia Lovaniensia Analecta 84) (Leuven 1998) 205-25.

Podskalsky G. and Cutler A. (1991) "Angel", in The Oxford Dictionary of Byzantium, vol. 1, ed. A. Kazhdan, vol. 1 (New York and Oxford 1991) 97. 
Ribak E. (2004) "Everyday artefacts as indicators of religious belief in Byzantine Palestine", in Secular Buildings and the Archaeology of Everyday Life in the Byzantine Empire, ed. K. Dark (Oxford 2004) 123-32.

Russell J. (1982) "Byzantine instrumenta domestica from Anemurium: the significance of context", in City, Town and Countryside in the Early Byzantine Era, ed. R. L. Hohlfelder (New York 1982) 133-54.

- (1995) "The archaeological context of magic in the Early Byzantine period", in Byzantine Magic, ed. H. Maguire (Dumbarton Oaks Papers) (Washington DC 1995) 35-50.

Sanders G. (2005) "Archaeological evidence for early Christianity and the end of Hellenic religion in Corinth", in Urban Religion in Roman Corinth. Interdisciplinary Approaches, edd. D. N. Schowalter and S. J. Friesen (Harvard Theological Studies 53) (Cambridge, Mass. 2005) 419-42.

Saradi-Mendelovici H. (1990) "Christian attitudes toward pagan monuments in Late Antiquity and their legacy in later Byzantine centuries", DOP 44 (1990) 47-61.

Snyder G. F. (2003) Ante Pacem. Archaeological Evidence of Church Life before Constantine, 2nd edn. (Mâcon 2003).

Talloen P. (2006) "Pious neighbours. Pisidian religious ties with Lycia. The case of the rider deities", in The 3rd International Symposium on Lycia, 07-10 November 2005, Antalya. Symposium Proceedings, 2, edd. K. Dörtluk et al. (Istanbul 2006) 747-59.

Talloen P. and Poblome J. (2005) “'What were they thinking of ?' Relief decorated pottery from Sagalassos. A cognitive approach", MEFRA 117.1 (2005) 55-81.

Thompson D. B. and Vickers M. (2003) "Terracottas", in The Oxford Classical Dictionary, edd. S. Hornblower and A. Spawforth (Oxford 2003) 1486.

Thür H. (2003) "Das spätantike Ephesos. Aspekte zur Frage der Christianisierung des Stadtbildes", in Die spätantike Stadt und ihre Christianisierung. Symposion vom 14. bis 16. Februar 2000 in Halle/Saale, edd. G. Brands and H.-G. Severin (SpätantikeFrühes Christentum - Byzanz. Kunst im ersten Jahrtausend. Reihe B: Studien und Perspektiven 11) (Wiesbaden 2003) 259-73.

Trombley F. R. (1978) "The council in Trullo (691-692): a study of the canons relating to paganism, heresy and the invasions, Comitatus 9 (1978) 1-18.

- (1985) "Paganism in the Greek world at the end of Antiquity: the case of rural Anatolia and Greece, HThR 78 (1985) 327-52.

Trombley F. R. (1993-94) Hellenic Religion and Christianization c. 370-529, 2 vols. (Religions in the Graeco-Roman World 115.1-2) (Leiden 1993-94).

Uhlenbrook J. (1986) Herakles. Passage of a Hero through 1000 Years of Classical Art (New York 1986).

Vaag L. E. (2001) "The stamped decoration on Phocaean Red Slip Ware", in Late Antiquity: Art in Context, edd. J. Fleischer, J. Lund and M. Nielsen (Danish Studies in Classical Archaeology. Acta Hyperborea 8) (Copenhagen 2001) 215-33.

Vikan G. (1991) "Amulet", in The Oxford Dictionary of Byzantium, vol. 1, ed. A. Kazhdan, vol. 1 (New York and Oxford 1991) 82-83.

Waelkens M. (1993) "Sagalassos. History and archaeology", in Sagalassos I. First General Report on the Survey (1986-1989) and Excavations (1990-1991), ed. M. Waelkens (Acta Archaeologica Lovaniensia. Monographiae 5) (Leuven 1993) 37-82.

Waelkens M. et al. (1997) "The 1994 and 1995 excavation seasons at Sagalassos", in Sagalassos IV. Report on the Survey and Excavation Campaigns of 1994 and 1995, edd. M. Waelkens and J. Poblome (Acta Archaeologica Lovaniensia. Monographiae 9) (Leuven 1997) 103-216.

(2000) "The Sagalassos Neon library mosaic and its conservation", in Sagalassos V. Report on the Survey and Excavation Campaigns of 1996 and 1997, edd. M. Waelkens and L. Loots (Acta Archaeologica Lovaniensia. Monographiae 11A) (Leuven 2000) 419-47. 
(2006) "The late antique to Early Byzantine city in southwest Anatolia. Sagalassos and its territory: a case study", in Die spätantike Stadt- Niedergang oder Wandel? Akten des internationalen Kolloquiums in München am 30. und 31. Mai 2003, edd. J.-U. Krause and C. Witschel (Historia Einzelschriften 190) (Stuttgart 2006) 199-255.

Waelkens M. and Talloen P. (in press) "Sagalassos", in The Encyclopaedia of Early Christian Art and Archaeology, ed. P. C. Finney (Grand Rapids, Michigan in press).

Whitby M. (1991) "John of Ephesus and the pagans. Pagan survivals in the sixth century", in Paganism in the Later Roman Empire and in Byzantium, ed. M. Salamon (Byzantina et Slavica Cracoviensia) (Cracow 1991) 111-31.

Zwirn S. (1999) "Ex-voto", in Late Antiquity. A Guide to the Postclassical World, edd. G. W. Bowersock, P. Brown and O. Grabar (Cambridge, Mass. and London 1999) 440-41.

\section{List OF Figures}

Fig. 1. Oinophoroi with Dionysiaca from Sagalassos: a) Oinophoros representing two busts of Dionysus, one of which is crowned by a standing winged Nike holding a palm branch, found at the Roman Baths of Sagalassos (inv. no. SA99RB2/64) and dated to the late 4th to early 5th c.; b) Oinophoros representing three busts of Dionysus underneath arcades preceded by members of the thiasos, found at an unknown location in Egypt where it is kept at the Museum for Egyptian Antiquities at Cairo (inv. no. J.E. 89081) and dated to the 5th c. (Sagalassos archive).

Fig. 2. Serving tray with a central medallion representing a drunken Dionysus supported by a satyr and accompanied by Pan, found at the Domestic Area (SA2001DA/93) and dated to the 2nd c. (Sagalassos archive).

Fig. 3. Statue of a drunken Dionysus supported by a satyr, from the left aedicula of the nymphaeum on the Upper Agora and dated to the 2nd c. (Sagalassos archive).

Fig. 4. Tufa blocks with inscribed crosses used to seal off the corner aediculae of the nymphaeum on the Upper Agora, dated to the 6th c. (Sagalassos archive).

Fig. 5. Christian symbols and scenes on Sagalassos Red Slip Ware: a) Mould for an oinophoros decorated with a Greek cross, found at the Potters' Quarter (SA2004PQ/37) and dated to the 5th to 6th c.; b) oil lamp with a cross-shaped handle, found at the market building to the north of the Upper Agora (SA1994UAN/174) and dated to the 5th to 6th c.; c) oil lamp displaying the sacrifice of Isaac, found on the Upper Agora (inv. no. SA1996UA/135) and dated to the 5th to 6th c. (Sagalassos archive).

Fig. 6. Mould for a tetragonal oinophoros representing a flying winged Nike holding a wreath, found at the Potters' Quarter (SA2004PQ/40) and dated to the late 5th to early 6th c. (Sagalassos archive).

Fig. 7. Ampulla with an adoratio scene from Sagalassos, kept at the British Museum (inv. no. MLA 1882.1-9.1) where it was brought from an unknown location in Asia Minor, and dated to the late 5 th c. (Hayes (1997) 88 pl. 36).

Fig. 8. Fragment of a hexagonal oinophoros with a stylised representation of the Eucharist, found on the Lower Agora (SA2003LA1/84) and dated to the late 5th to early 6 th c. (Sagalassos archive).

Fig. 9. Terracotta figurine of a warrior on horseback, found at the Bouleuterion (inv. no. SA2000B1/164) and dated to the late 5th to early 6th c. (Sagalassos archive).

Fig. 10. Terracotta figurine of a Christian priest or saint (on horseback) found at the Doric Temple (inv. no. SA1991DT/347) and dated to the late 5th to early 6th c. (Sagalassos archive).

Fig. 11. Terracotta mask representing a helmeted warrior, found on the Lower Agora (inv. no. SA2003LA1/79) and dated to the 6th c. (Sagalassos archive).

Fig. 12. Terracotta figurine of an unidentified four-legged animal with a cross incised 
on its back, found at the Bouleuterion (inv. no. SA1998B1/28) and dated to the late 5 th to early 6th c. (Sagalassos archive).

Fig. 13. Two Tintinnabula or bronze bells, found at the Doric Fountain House (SA1991N/577) and dated to the 5th to 6th c. (Sagalassos archive).

Fig. 14. Leaded bronze medallion representing Solomon on horseback striking down a prostrate female demon, found at the market building to the north of the Upper Agora (SA1995UAN/159) and dated to the 6th c. (Sagalassos archive).

Fig. 15. Oinophoros depicting two doves flanking a central kantharos, found at the Domestic Area (inv no. SA2002DAl/106) and dated to the late 6th to 7th c. (Sagalassos archive). 